\title{
Article \\ Effects of Genetic Background and Altitude on Sugars, Malic Acid and Ascorbic Acid in Fruits of Wild and Cultivated Apples (Malus sp.)
}

\author{
Yajing Li ${ }^{1,+}$, Hongxia Sun ${ }^{1,+}{ }^{+}$, Jindong Li $^{1}$, Shu Qin ${ }^{1}$, Wei Yang ${ }^{2}$, Xueying Ma ${ }^{2} \mathbb{D}$, Xiongwu Qiao $^{1}$ \\ and Baoru Yang ${ }^{1,2, *(D)}$
}

Citation: Li, Y.; Sun, H.; Li, J.; Qin, S.; Yang, W.; Ma, X.; Qiao, X.; Yang, B. Effects of Genetic Background and Altitude on Sugars, Malic Acid and Ascorbic Acid in Fruits of Wild and Cultivated Apples (Malus sp.). Foods 2021, 10, 2950. https://doi.org/ $10.3390 /$ foods 10122950

Academic Editor: Lorenzo Zacarías

Received: 18 October 2021

Accepted: 26 November 2021

Published: 30 November 2021

Publisher's Note: MDPI stays neutral with regard to jurisdictional claims in published maps and institutional affiliations.

Copyright: (c) 2021 by the authors. Licensee MDPI, Basel, Switzerland. This article is an open access article distributed under the terms and conditions of the Creative Commons Attribution (CC BY) license (https:// creativecommons.org/licenses/by/ $4.0 /)$.
1 Shanxi Center for Testing of Functional Agro-Products, Shanxi Agricultural University, Taiyuan 030031, China; sakura_yj@163.com (Y.L.); anty0070@163.com (H.S.); ljdchemistry@163.com (J.L.); qinshu55@126.com (S.Q.); qiaoxiongwu@126.com (X.Q.)

2 Department of Biochemistry, Food Chemistry and Food Development, University of Turku, Turun Yliopisto, FI-20014 Turku, Finland; wei.yang@utu.fi (W.Y.); xueying.ma@utu.fi (X.M.)

* Correspondence: baoru.yang@utu.fi

+ Both authors contributed equally to this work.

\begin{abstract}
Soluble sugars, malic acid, and ascorbic acid in 17 apple cultivars (Malus domestica Borkh.) and three wild forms (M. pumila 'Saiwaihong', M. prunifolia (Willd.) Borkh. and M. micromalus Makino) from three major apple cultivation regions in China were quantified using gas chromatography equipped with flame ionization detector (GC-FID). Fructose was the most abundant sugar, followed by sucrose, glucose, and sorbitol. Wild apples contain more sorbitol and less sucrose and were significantly more acidic than cultivated fruits. The total sugar content varied from 110 to $160 \mathrm{mg} / \mathrm{g}$ fresh fruits, total acid content from 2 to $6 \mathrm{mg} / \mathrm{g}$, with a strong influence of genetic background and growth location. Overall, 'Gala', 'Xiali', 'Liuyuehong', 'Lihong', 'Starking Delicious', and 'Starkrimson' were characterized by higher sugar/acid ratio indicating sweeter taste compared to other cultivars. The wild apples had the highest content of ascorbic acid (0.6-0.96 mg/g). Compared to other cultivars, 'Zhongqiuwang', 'Qinguan', and 'Nagafu No. 2' were richer in ascorbic acid. The ascorbic acid content in the commercial cultivars was highly dependent on growth location. The content of malic acid and sucrose positively correlated to altitude, and that of glucose negatively. Malic acid positively correlated with ascorbic acid and sucrose, glucose content with ascorbic acid.
\end{abstract}

Keywords: acids; altitude; apple; ascorbic acid; cultivars; growth site; Malus sp.; species; sugars

\section{Introduction}

Apple (Malus $\times$ domestica Borkh.) is one of the most widely produced and consumed fruits in the world. In 2018, the global apple production reached 86.1 million tons, with China being the largest producer (46\% of global production), followed by the US (5.4\%), Poland (4.6\%), Turkey (4.2\%), and Iran (2.9\%) [1]. More than 7500 apple varieties are documented worldwide, many of which are closely related to the major adaptable genotypes, for example, 'Red Delicious', 'Golden Delicious', 'Jonathan' and 'McIntosh' [2-4].

As a fruit available on the market throughout the year, apple is an important part of the diet and an excellent source of nutrients and health-promoting bioactive compounds [5]. Apple components may reduce the risk of chronic diseases by various mechanisms, and their potential roles in supporting human health have been well summarized [6,7]. Research has been conducted on the phytochemical components in fruits of multiple varieties cultivated in major producing countries, such as China, Poland, Italy, New Zealand, and Austria [8-12]. Among the major components of apple, sugars and acids are the most important compounds, which have a strong impact on the overall organoleptic quality of the fruits $[13,14]$. Sweet and sour tastes are considered to be among the most important sensory properties determining the consumer preference of apples $[15,16]$, which largely 
depends on the content and compositional profile of soluble sugars and organic acids, and more importantly, the balance between organic acids and sugars as reflected by sugar/acid ratio $[17,18]$. In mature apples, fructose is the principal sugar, followed by glucose and sucrose, while malic acid is the most dominant organic acid [12,19].

Sugars not only determine fruit sweetness, but also provide carbon sources for the synthesis of other components such as pigments, amino acids, vitamins, and aroma compounds [20]. Fruit acids have been shown to have various health-supporting activities. Malic acid has been suggested to have potential health promoting effects including regulating urinary $\mathrm{pH}$, alleviating dry mouth, protecting cardiovascular system, and inhibiting $\alpha$-glucosidase activity [21-24]. In addition, ascorbic acid is one of the most important nutritional factors in fruits acting as an antioxidant [25].

Many factors can influence the composition and quality of fruits [26]. Genotype is one of the key factors affecting the biochemical and physicochemical characteristics, and therefore sensory properties of the fruits of apple cultivars [18]. Both the content and profile of sugars and acids vary considerably among cultivars and species of apple [19]. The ripening time of apples is primarily determined by genetic factors but also influenced by the growth environment. Differences in fruit composition have been reported between cultivars with different ripening times during the year [27]. For example, Wu et al. found that the early-ripening apples had lower contents of soluble solids compared to the middle and late-ripening cultivars [12].

In addition to genetic factors, various pre-harvest factors, especially the temperature and light variables of the growth sites, also play an important role in determining the composition and quality of apple fruits [28]. The difference in altitudes of growth sites is associated with variation in temperature, intensity and quality of light, day/night variation, and humidity, which are known to be key factors influencing the photosynthesis and secondary metabolism of plants [28]. Therefore, the compositional characteristics and quality factors of apple fruits produced in a specific area represent the outcome of a complex interplay of genetic and environmental factors and cultivation practices applied [13,29]. The fruits of 'Golden Delicious' cultivated at a lower altitude $(600 \mathrm{~m})$ had larger fruit sizes and higher content of soluble solids and titratable acids than the fruits of the same cultivar cultivated at a higher altitude $(1000 \mathrm{~m})$ [28]. In another study on the composition of the fruit peel of 'Fujiku' apple, the high-altitude environment increased the levels of carbohydrates, anthocyanin, and some flavanol glycosides, but decreased the levels of glutamic acid and several related proteins [30].

Shanxi Province, located in the eastern part of the Loess Plateau, is one of the four major apple-producing areas in China. In 2017, the apple production of Shanxi Province was 4.45 million tons representing about $10 \%$ of the apple production in China [31]. The main apple-producing regions in Shanxi province are Yuncheng, Jinzhong, and Linfen districts, which have been included in the 'National Plan for Advantageous Regional Development of Apples' of China [32]. Despite the importance of global apple production, little information is available about the chemical composition of the apples produced in these regions. Thorough knowledge about compositional parameters of the apple varieties and factors influencing the composition is not only essential for the evaluation of the quality of apple fruits, but also provides important guidance for plant breeding, cultivation, and industrial processing.

In the present study, apple fruits of seventeen cultivars and three wild forms were harvested from three major apple cultivation regions (Yuncheng City, Jinzhong City, and Linfen City), in Shanxi Province, China. In addition, fruits of two apple cultivars cultivated at high altitudes in Yunnan Province were also studied for comparison. The first aim of the study was to obtain systematic information on the overall content and composition of sugars and acids in the fruits of the major apple resources cultivated in these regions. Our aim was also to compare the composition among major cultivars and species of apples in China. Special attention was placed on the impact of growth altitudes and fruit-ripening time on the composition and content of sugars and acids in apple fruits. The results provide 
important information for evaluating the quality of apple fruits produced in these regions and for guiding the cultivation, plant breeding, as well as processing of apples.

\section{Materials and Methods}

\subsection{Apple Samples}

Fresh fruits of 17 apple cultivars and three wild forms were harvested from three growth regions (Yuncheng City, Jinzhong City, and Linfen City) at different altitudes, representing the major apple-producing regions in Shanxi Province, China. The altitudes of these three sites were 400-800 m, 800-1000 m, and 900-1200 m, respectively. Fruits of two cultivars 'Qinguan' and 'Xinshiji' were also collected from an orchard at a higher altitude (over $2000 \mathrm{~m}$ ) in Yunnan Province, in addition to the three locations in Shanxi Province. Moreover, among these 20 varieties collected in the present study, 4 varieties were harvested in August 2018, 9 varieties were harvested in September, and 7 varieties were harvested in October. Table 1 presents detailed information of the samples studied including varieties, ripening times, and growth sites. The fruit samples were harvested as optimal ripe at the commercial harvest time typical of each cultivar. About 20 fruits for each cultivar and 50 fruits for each wild form were pooled from a large batch consisting of fruits collected from multiple trees, and the pooled batch was randomly divided into 5 parts, each representing one biological replicate. The fresh fruits were stored at $0{ }^{\circ} \mathrm{C}$ until analysis within 4 months after harvesting.

Table 1. Information of apple samples studied.

\begin{tabular}{|c|c|c|c|c|}
\hline Apples & Abbreviation & Ripening Time & Growth Site ${ }^{1}$ & Altitude (m) \\
\hline \multicolumn{5}{|c|}{ Cultivated Apples (Malus domestica Borkh.) } \\
\hline Gala & GL & August & $\begin{array}{l}\text { Yuncheng } \\
\text { Jinzhong }\end{array}$ & $\begin{array}{c}400-800 \\
800-1000\end{array}$ \\
\hline Xiali & $\mathrm{XL}$ & August & Jinzhong & $800-1000$ \\
\hline American No. 8 & USA-8 & August & Jinzhong & $800-1000$ \\
\hline Liuyuehong & LYH & August & Jinzhong & $800-1000$ \\
\hline Lihong & LH & September & Jinzhong & 800-1000 \\
\hline Starking Delicious & STA-D & September & Jinzhong & $800-1000$ \\
\hline Zhongqiuwang & ZQW & September & Linfen & $900-1200$ \\
\hline Xinshiji & XSJ & September & $\begin{array}{l}\text { Yuncheng } \\
\text { Yunnan }\end{array}$ & $\begin{array}{c}400-800 \\
\text { Over } 2000\end{array}$ \\
\hline Starkrimson & STA & September & $\begin{array}{l}\text { Yuncheng } \\
\text { Jinzhong } \\
\text { Linfen }\end{array}$ & $\begin{array}{c}400-800 \\
800-1000 \\
900-1200\end{array}$ \\
\hline Golden Delicious & GOL-D & September & $\begin{array}{l}\text { Yuncheng } \\
\text { Jinzhong } \\
\text { Linfen }\end{array}$ & $\begin{array}{c}400-800 \\
800-1000 \\
900-1200\end{array}$ \\
\hline Red General Fuji & RGF & September & $\begin{array}{l}\text { Yuncheng } \\
\text { Jinzhong } \\
\text { Linfen }\end{array}$ & $\begin{array}{c}400-800 \\
800-1000 \\
900-1200\end{array}$ \\
\hline Nagafu No. 2 & NF-2 & October & $\begin{array}{l}\text { Yuncheng } \\
\text { Jinzhong } \\
\text { Linfen }\end{array}$ & $\begin{array}{c}400-800 \\
800-1000 \\
900-1200\end{array}$ \\
\hline Huimin Fuji & $\mathrm{HF}$ & October & $\begin{array}{c}\text { Yuncheng } \\
\text { Linfen }\end{array}$ & $\begin{array}{c}400-800 \\
900-1200\end{array}$ \\
\hline Yantai Fuji No. 3 & YF-3 & October & $\begin{array}{l}\text { Yuncheng } \\
\text { Linfen }\end{array}$ & $\begin{array}{c}400-800 \\
900-1200\end{array}$ \\
\hline Yantai Fuji No. 6 & YF-6 & October & Yuncheng & $500-800$ \\
\hline Qiufu No. 1 & QF-1 & October & Linfen & $900-1200$ \\
\hline
\end{tabular}


Table 1. Cont.

\begin{tabular}{|c|c|c|c|c|}
\hline Apples & Abbreviation & Ripening Time & Growth Site ${ }^{1}$ & Altitude (m) \\
\hline Qinguan & QG & October & $\begin{array}{l}\text { Yuncheng } \\
\text { Linfen } \\
\text { Yunnan }\end{array}$ & $\begin{array}{c}400-800 \\
900-1200 \\
\text { Over } 2000\end{array}$ \\
\hline \multicolumn{5}{|c|}{ Wild Apples (Malus genus) } \\
\hline \multicolumn{2}{|c|}{ M. pumila 'Saiwaihong' } & September & Linfen & $900-1200$ \\
\hline \multicolumn{2}{|c|}{ M. prunifolia (Willd.) Borkh. } & September & Jinzhong & $800-1000$ \\
\hline \multicolumn{2}{|c|}{ M. micromalus Makino } & October & Jinzhong & $800-1000$ \\
\hline
\end{tabular}

${ }^{1}$ Yuncheng, Jinzhong, and Linfen represent three growth sites in Shanxi Province, and Yunnan represents the growth site in Yunnan Province.

After the removal of seeds, the fresh apples were cut into dices and immediately mixed with dry ice and ground to a fine powder using a Knife Mill (GRINDOMIX GM 300, Retsch, Germany). The powdered samples were then stored at $-20{ }^{\circ} \mathrm{C}$ until analysis.

\subsection{Standards and Chemicals}

For the identification and quantification of the soluble sugars and acids, standard compounds of fructose, sucrose, glucose, malic acid, and tartaric acid were acquired from Shanghai Yuanye Bio-Technology Co., Ltd. (Shanghai, China). Sorbitol, adonitol, and ascorbic acid were obtained from Dr. Ehrenstorfer GmbH (Augsburg, Germany).

\subsection{Chemical Analysis}

\subsubsection{Analysis of Sugars, Malic Acid, and Ascorbic Acid}

About five grams of apple powder were weighed accurately and $15 \mathrm{~mL}$ MilliQ water was added. After thorough mixing and shaking at $250 \mathrm{rpm} / \mathrm{min}$ for $5 \mathrm{~min}$, the mixture was centrifuged at $16,000 \times g$ for $10 \mathrm{~min}$. The supernatant was collected and filtered into a $50 \mathrm{~mL}$ volumetric flask with a qualitative filtering paper. The extraction process was repeated three times, and the supernatants were combined, and the final volume was filled up to $50 \mathrm{~mL}$ with MilliQ water. Then, $1 \mathrm{~mL}$ of the extract was taken, filtered through a $0.22 \mu \mathrm{m}$ Millipore membrane, and used for the analysis of sugars and acids, the remaining solution was used for $\mathrm{pH}$ determination with a $\mathrm{pH}$ meter (INESA, Shanghai, China).

An aliquot of $50 \mu \mathrm{L}$ extract was placed in auto-sampler bottles. Tartaric acid $(50 \mu \mathrm{L}$, $0.5 \mathrm{mg} / \mathrm{mL})$ and adonitol $(50 \mu \mathrm{L}, 2 \mathrm{mg} / \mathrm{mL})$ were added as internal standards for acids and sugars, respectively. The solution was evaporated to dryness under a nitrogen flow ( $40{ }^{\circ} \mathrm{C}, 40-60 \mathrm{~min}$ ). TMS-derivatives were prepared by adding $195 \mu \mathrm{L}$ of Tri-Sil HTP (Thermo Fisher Scientific, Rockford, IL, USA) reagent, shaking vigorously with a Vortex (EOFO-945066, Talboys, Thorofare, NJ, USA) for $5 \mathrm{~min}$, and followed by incubating at $60{ }^{\circ} \mathrm{C}$ (heat block) for $30 \mathrm{~min}$. The sample was then cooled to room temperature and transferred into a $300 \mu \mathrm{L}$ glass insert placed in an autosampler bottle for GC-FID analyses. The TMS-derivatized samples were analyzed with an Agilent 7890B gas chromatograph equipped with a flame ionization detector. The analyses were carried out with an SPB-1 column $(30 \mathrm{~m} \times 0.25 \mathrm{~mm}$ i.d. $\times 0.25 \mu \mathrm{m} \mathrm{df})$ (Supelco, Bellefonte, PA, USA). A sample of 1 $\mu \mathrm{L}$ was injected with an auto-sampler into the injector set in split mode (split ratio of 1:10). The flow rate of the carrier gas helium was $2 \mathrm{~mL} / \mathrm{min}$. The temperature of the injector was $210{ }^{\circ} \mathrm{C}$, and the temperature of the detector was $250^{\circ} \mathrm{C}$. The column temperature program was set at an initial temperature of $130^{\circ} \mathrm{C}$ held for three $3 \mathrm{~min}$, raised to $180^{\circ} \mathrm{C}$ at a rate of $30^{\circ} \mathrm{C} / \mathrm{min}$, and held at $180^{\circ} \mathrm{C}$ for $10 \mathrm{~min}$, raised to the final temperature of $290^{\circ} \mathrm{C}$ at a rate of $40^{\circ} \mathrm{C} / \mathrm{min}$, and held at $290^{\circ} \mathrm{C}$ for $5 \mathrm{~min}$.

The sugars and acids were identified by co-injection with reference compounds. The quantification of the compounds was carried out by comparing the peak areas of the analytes with those of the internal standards. Individual correction factors, determined by analysis of reference compounds, were applied to correct the difference in detector response between the internal standards and the analytes. The total content of acids and 
the total sugar content were calculated as the sum of individual compounds within the respective group and were used to calculate the sugar/acid ratio for each sample.

\subsubsection{Solid Matter Determination}

For the determination of the content of soluble solid matters, juices were pressed from thawed apple flesh powders using four layers of gauze. The content of soluble solids was measured using a PR- $32 \alpha$ refractometer ( $0-32{ }^{\circ}$ Brix, Atago, Tokyo, Japan) and is expressed as ${ }^{\circ}$ Brix.

\subsection{Statistical Analysis}

The mean values and standard deviations of each of the parameters studied including the content of individual sugars and acids as well as the total sugar content and the total content of acids, sugar/acid ratio, $\mathrm{pH}$, and soluble solids were calculated. One-way analysis of variance (ANOVA) was performed for multiple comparisons, and independent-samples t-test was used to investigate the difference between the samples of the same cultivar collected at two altitudes. The above statistical analyses were all carried out with SPSS 24 (SPSS, Inc., Chicago, IL, USA). In order to show the distribution of these parameters among the samples studied, the box-plots were drawn using Origin 9 (Origin Lab Co., Northampton, MA, USA). The hierarchical cluster analysis and correlation analysis were also carried out with SPSS 24 program. Hierarchical cluster analysis was performed for the cultivated and wild apples using Squared Euclidean distance coefficient and Between-group linkage method. Correlation analysis was performed using Pearson Correlation Coefficient. Principal component analysis (PCA) was performed using The Unscrambler $\times 10.4$ (CAMO ASA, Trondheim, Norway) to identify the key factors differentiating the apple samples.

\section{Results and Discussion}

\subsection{Compositional Profile of Sugars and Acids in Cultivated and Wild Apples}

The sugars and acids identified and the content of these compounds in the apple samples are presented in Table 2. The major soluble sugars in the apple fruits are fructose, sucrose, and glucose; sorbitol was major sugar alcohol, which is consistent with previous reports on sugars and sugar alcohols in apple fruits of different cultivars $[15,19,33]$. The ranges of distribution of the content of the sugars and acids are presented in Figure 1. For most of the apple cultivars investigated in this study, fructose $(46-74 \mathrm{mg} / \mathrm{g}$ fresh weight) was the most dominating sugar, followed by sucrose $(17-87 \mathrm{mg} / \mathrm{g})$, glucose $(17-54 \mathrm{mg} / \mathrm{g})$, and a sugar alcohol sorbitol $(2-13 \mathrm{mg} / \mathrm{g})$. However, there were exceptions to this order of abundance. The content of sucrose was higher than that of fructose in the fruits of the cultivar 'Qinguan' (sucrose, $49 \mathrm{mg} / \mathrm{g}$; fructose, $46 \mathrm{mg} / \mathrm{g}$ ) and 'Xinshiji' (sucrose, $87 \mathrm{mg} / \mathrm{g}$; fructose, $57 \mathrm{mg} / \mathrm{g}$ ) harvested from Yunnan province as well as the fruits of the wild apple variety M. pumila 'Saiwaihong' (sucrose, $77 \mathrm{mg} / \mathrm{g}$; fructose, $50 \mathrm{mg} / \mathrm{g}$ ) collected from Linfen, Shanxi Province. In addition, glucose was the second most abundant soluble sugar with content higher than the level of sucrose in 'Xinshiji' and 'Yantai Fuji No.6' harvested in Yuncheng and two wild apples (M. prunifolia (Willd.) Borkh. and M. micromalus Makino), although the situation was vice versa for 'Xinshiji' harvested in Yunnan and 'Yantai Fuji No.6' harvested in Linfen. Both genetic background and environment may have contributed to the variation in the relative abundance of different sugar compounds. M. pumila 'Saiwaihong' belongs to griggles with an average single fruit weight of $58.3 \mathrm{~g}$, falling between the fruit sizes of cultivated and wild apples [34]. The altitude of the growth site in Yunnan Province was over $2000 \mathrm{~m}$ being much higher than the altitudes of the growth sites in Shanxi Province (400-1200 m), which may explain the difference in the composition compared to the fruits of the same cultivars harvested from Shanxi Province. Previous research has also shown variations in the relative abundance of sucrose and glucose in apple fruits of the same cultivars grown in different countries indicating the influence of environmental factors and horticultural practices. For example, the fruits of 
the cultivar 'Golden Delicious' had a higher content of sucrose than that of glucose in the study of Petkovsek [35] as in the current study, whereas others reported vice versa [12].

In mature fruits of 364 apple accessions originated from different countries and cultivated in the research orchard of Xingcheng Institute of Pomology of the Chinese Academy of Agricultural Sciences (Xingcheng, China), the average content of fructose, sucrose, and glucose were 36,40 , and $17 \mathrm{mg} / \mathrm{g}$ (FW), respectively. In the fruits of 321 cultivars, the average contents of fructose $(35 \mathrm{mg} / \mathrm{g})$ and sucrose $(44 \mathrm{mg} / \mathrm{g})$ were $2-3$ times higher than that of glucose $(14 \mathrm{mg} / \mathrm{g})$. In contrast, the wild apples contained more fructose $(41 \mathrm{mg} / \mathrm{g})$ and glucose $(37 \mathrm{mg} / \mathrm{g})$ than sucrose $(12 \mathrm{mg} / \mathrm{g})$ [19]. The same study reported that the total sugar contents ranged from 46 to $185 \mathrm{mg} / \mathrm{g}$ (FW) in the 321 cultivars [19]. In addition, the total sugar contents in apple fruits of 8 cultivars from integrated cultivation and 11 varieties organically grown in Austria ranged 115-183 mg/g (FW) and 110-200 mg/g (FW), respectively, with fructose and sucrose being clearly more abundant than glucose. Among the 7 cultivars from integrated cultivation, 'Jonagold' had the highest total sugar content (183 mg/g), followed by 'Fuji' (140 mg/g), 'Golden Delicious' (135 mg/g), and 'Gala' $(115 \mathrm{mg} / \mathrm{g})$ [36]. In the current study, the total sugar content fell in a similar range. The lowest total sugar content was $106 \mathrm{mg} / \mathrm{g}$ f.w. in 'Yantai Fuiji No. 6' cultivated in Yuncheng, and the highest $(169 \mathrm{mg} / \mathrm{g})$ in 'Saiwaihong' from Linfen. The fruits of 'Nagafu' harvested from Jinzhong and Linfen had total sugar content close to $160 \mathrm{mg} / \mathrm{g}$ f.w., being the highest among the commercial cultivars. In our study, the total sugar content in 'Gala' $(130 \mathrm{mg} / \mathrm{g}$ and $133 \mathrm{mg} / \mathrm{g}$ ) cultivated in Shanxi was higher than the content reported in fruits of 'Gala' grown in Austria. The total sugar content in 'Golden Delicious' varied from 113 (Yuncheng) and $119 \mathrm{mg} / \mathrm{g}$ (Linfen) to $144 \mathrm{mg} / \mathrm{g}$ (Jinzhong).

Among the organic acids, malic acid is known to be the most abundant, accounting for about $90 \%$ of the total organic acids in ripe apple fruits [19]. Consistent with previous studies, malic acid is the dominant organic acid in the fruits of apple cultivars and species investigated in this study. The content of malic acid ranged $2-19 \mathrm{mg} / \mathrm{g} \mathrm{FW}$, the highest content in the two wild forms (9.7 in M. micromalus Makino and 18.7 in M. prunifolia (Willd.) Borkh.) (Table 2 and Figure 1). Among the commercial cultivars studied, 'Golden Delicious' harvested from Linfen had the highest content of malic acid ( $5 \mathrm{mg} / \mathrm{g}$ f.w.), whereas the lowest levels (around $2 \mathrm{mg} / \mathrm{g}$ f.w.) were found in 'Liuyuehong', 'Starkrimson', 'Starking Delicious', and 'Xiali' cultivated in Jinzhong, and 'Gala' cultivated in Yuncheng.

In a study of 18 commercial cultivars, the content of total acids ranged from $6.3-17.9 \mathrm{mg} / \mathrm{g}$ (FW) [36]. Ma et.al [19] quantitatively analyzed the malic acid in mature fruits of 364 apple accessions, and the content ranged from 0.5 to $22.7 \mathrm{mg} / \mathrm{g}$ (FW), the levels being significantly higher in wild apples than in commercial apple cultivars. High content of malic acid is known to contribute to sourness, bitterness, and astringency of fruits and berries. Therefore, it can be anticipated that wild apples are generally characterized by a higher intensity of sour taste and astringent mouthfeel.

The sugar/acid ratio ranged from 7 in the fruits of the wild apple species M. micromalus Makino to 68 in those of 'Liuyuehong' cultivated in Jinzhong. The sugar/acid ratio is an important compositional parameter with a strong impact on the sensory properties of fruits. A high sugar/acid ratio is directly correlated to high intensities of sweetness. Previous research showed that apple fruits with sugar/acid ratios below 20 have a strong sour taste and are suitable only for processing, while fruits with sugar/acid ratios higher than this value are often perceived as sweet and proper for direct consumption as fresh fruits [13]. Although all the commercial cultivars investigated in the current study had sugar/acid ratios above 20, there was a wide range of variation among the samples of different cultivars and different growth locations, indicating possible differences in sensory properties of the fruits. In contrast to the low sugar/acid in the wild forms M. micromalus Makino and M. prunifolia (Willd.) Borkh., M. pumila 'Saiwaihong' has sugar/acid ratio close to 30. Indeed, 'Saiwaihong' has been cultivated as a commercial variety due to its good sensory properties. 


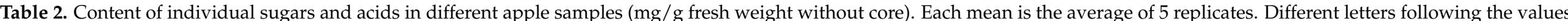

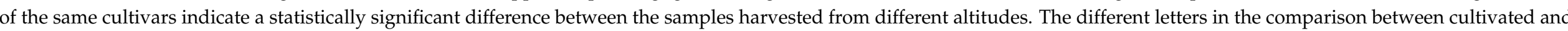
wild apples indicate statistically significant differences.

\begin{tabular}{|c|c|c|c|c|c|c|c|c|c|c|c|c|}
\hline Cultivars & $\begin{array}{l}\text { Growth } \\
\text { Sites }\end{array}$ & $\begin{array}{l}\text { Malic Acid } \\
\text { (mg/g) }\end{array}$ & $\begin{array}{l}\text { Ascorbic } \\
\text { Acid } \\
(\mathrm{mg} / \mathrm{g})\end{array}$ & $\begin{array}{c}\text { Fructose } \\
\text { (mg/g) }\end{array}$ & $\begin{array}{c}\text { Sorbitol } \\
\text { (mg/g) }\end{array}$ & $\begin{array}{c}\text { Glucose } \\
\text { (mg/g) }\end{array}$ & $\begin{array}{l}\text { Sucrose } \\
(\mathrm{mg} / \mathrm{g})\end{array}$ & $\begin{array}{c}\text { Total Acid } \\
\text { (mg/g) }\end{array}$ & $\begin{array}{l}\text { Total Sugar } \\
(\mathrm{mg} / \mathrm{g})\end{array}$ & Sugar/Acid & $\mathrm{pH}$ & $\begin{array}{l}\text { Soluble } \\
\text { Solids } \\
\left({ }^{\circ} \text { Brix }\right)\end{array}$ \\
\hline \multicolumn{13}{|c|}{ Cultivated Apples (Malus domestica Borkh.) Collected from One Site } \\
\hline $\begin{array}{l}\text { American } \\
\text { No. } 8\end{array}$ & Jinzhong & $2.39 \pm 0.33$ & $0.13 \pm 0.03$ & $58.81 \pm 2.97$ & $4.66 \pm 0.93$ & $10.39 \pm 0.82$ & $53.91 \pm 6.60$ & $2.52 \pm 0.35$ & $127.77 \pm 8.94$ & $51.46 \pm 7.97$ & $4.30 \pm 0.07$ & $12.44 \pm 0.60$ \\
\hline Liuyuehong & Jinzhong & $1.95 \pm 0.03$ & $0.20 \pm 0.04$ & $63.99 \pm 0.85$ & $10.52 \pm 0.25$ & $18.04 \pm 0.30$ & $53.48 \pm 1.63$ & $2.15 \pm 0.05$ & $146.03 \pm 2.83$ & $68.04 \pm 0.96$ & $4.55 \pm 0.01$ & $14.64 \pm 0.11$ \\
\hline $\begin{array}{l}\text { Starking } \\
\text { Delicious }\end{array}$ & Jinzhong & $2.10 \pm 0.14$ & $0.05 \pm 0.03$ & $67.52 \pm 2.24$ & $4.01 \pm 0.51$ & $20.18 \pm 1.91$ & $34.05 \pm 2.92$ & $2.14 \pm 0.12$ & $125.76 \pm 4.26$ & $58.92 \pm 5.34$ & $4.44 \pm 0.05$ & $13.30 \pm 0.31$ \\
\hline Zhongqiuwang & Linfen & $3.22 \pm 0.33$ & $0.37 \pm 0.04$ & $69.43 \pm 2.00$ & $2.99 \pm 0.38$ & $20.56 \pm 2.16$ & $34.61 \pm 12.73$ & $3.59 \pm 0.37$ & $127.59 \pm 13.23$ & $35.73 \pm 4.15$ & $4.03 \pm 0.07$ & $13.74 \pm 0.81$ \\
\hline $\begin{array}{l}\text { Yantai Fuji } \\
\text { No. } 6\end{array}$ & Yuncheng & $2.37 \pm 0.08$ & $0.07 \pm 0.02$ & $60.27 \pm 0.70$ & $2.38 \pm 0.04$ & $27.57 \pm 0.24$ & $15.81 \pm 3.02$ & $2.44 \pm 0.10$ & $106.03 \pm 2.78$ & $43.42 \pm 0.75$ & $4.29 \pm 0.01$ & $11.76 \pm 0.09$ \\
\hline Qiufu No. 1 & Linfen & $4.07 \pm 0.31$ & $0.16 \pm 0.07$ & $70.81 \pm 3.66$ & $6.61 \pm 1.03$ & $25.24 \pm 1.31$ & $44.90 \pm 3.86$ & $4.24 \pm 0.30$ & $147.57 \pm 4.83$ & $34.93 \pm 2.12$ & $4.09 \pm 0.03$ & $15.48 \pm 0.52$ \\
\hline \multicolumn{13}{|c|}{ Comparison among Different Sites of the Same Commercial Cultivars (Malus domestica Borkh.) } \\
\hline Gala & Jinzhong & $2.81 \pm 0.38^{\mathrm{a}}$ & $0.10 \pm 0.06^{\mathrm{a}}$ & $64.85 \pm 5.33^{\mathrm{a}}$ & $2.98 \pm 0.74^{\mathrm{a}}$ & $18.05 \pm 2.09^{b}$ & $48.47 \pm 2.74^{\mathrm{a}}$ & $2.90 \pm 0.41^{\mathrm{a}}$ & $132.85 \pm 9.75^{\mathrm{a}}$ & $46.16 \pm 4.04^{b}$ & $4.17 \pm 0.07^{b}$ & $13.36 \pm 0.99^{\mathrm{a}}$ \\
\hline \multirow{2}{*}{ Xinshiji } & Yuncheng & $4.39 \pm 0.57^{\mathrm{a}}$ & $0.25 \pm 0.05^{\mathrm{a}}$ & $62.97 \pm 3.64^{\mathrm{a}}$ & $8.70 \pm 2.08^{a}$ & $36.43 \pm 1.92^{\mathrm{a}}$ & $22.51 \pm 7.78^{b}$ & $4.64 \pm 0.56^{\mathrm{a}}$ & $127.44 \pm 8.80^{\mathrm{b}}$ & $27.63 \pm 1.87^{b}$ & $4.20 \pm 0.10^{\mathrm{a}}$ & $14.88 \pm 0.75^{\mathrm{a}}$ \\
\hline & Yunnan & $3.80 \pm 0.59^{\mathrm{a}}$ & $0.18 \pm 0.03^{b}$ & $56.59 \pm 4.11^{b}$ & $3.27 \pm 0.48^{b}$ & $16.65 \pm 2.60^{b}$ & $87.22 \pm 17.68^{a}$ & $3.98 \pm 0.61^{a}$ & $164.70 \pm 13.00^{\mathrm{a}}$ & $41.93 \pm 4.91^{\mathrm{a}}$ & $4.24 \pm 0.07^{a}$ & $13.84 \pm 0.30^{\mathrm{b}}$ \\
\hline \multirow{3}{*}{ Starkrimson } & Yuncheng & $3.75 \pm 0.29^{\mathrm{a}}$ & $0.24 \pm 0.23^{\mathrm{a}}$ & $53.17 \pm 3.27^{b}$ & $3.30 \pm 0.56^{b}$ & $23.49 \pm 2.46^{\mathrm{a}}$ & $31.41 \pm 4.85^{\mathrm{b}}$ & $3.99 \pm 0.34^{\mathrm{a}}$ & $111.37 \pm 5.70^{b}$ & $28.07 \pm 2.25^{c}$ & $4.33 \pm 0.05^{b}$ & $12.00 \pm 0.35^{b}$ \\
\hline & Jinzhong & $2.05 \pm 0.06^{\mathrm{c}}$ & $0.05 \pm 0.02^{a}$ & $65.1 \pm 4.20^{\mathrm{a}}$ & $5.03 \pm 1.17^{\mathrm{a}}$ & $21.89 \pm 1.78^{\mathrm{a}}$ & $33.11 \pm 3.49^{b}$ & $2.10 \pm 0.08^{\mathrm{c}}$ & $125.13 \pm 5.68^{a}$ & $59.73 \pm 4.44^{\mathrm{a}}$ & $4.57 \pm 0.04^{\mathrm{a}}$ & $13.62 \pm 0.72^{a}$ \\
\hline & Linfen & $2.61 \pm 0.35^{b}$ & $0.09 \pm 0.03^{a}$ & $54.98 \pm 2.79^{b}$ & $3.31 \pm 0.87^{b}$ & $21.68 \pm 1.25^{\mathrm{a}}$ & $46.63 \pm 8.84^{\mathrm{a}}$ & $2.71 \pm 0.35^{b}$ & $126.59 \pm 10.91^{\mathrm{a}}$ & $47.31 \pm 6.29^{a}$ & $4.24 \pm 0.05^{\mathrm{c}}$ & $12.06 \pm 0.70^{\mathrm{b}}$ \\
\hline \multirow{3}{*}{$\begin{array}{l}\text { Golden } \\
\text { Delicious }\end{array}$} & Yuncheng & $2.49 \pm 0.30^{c}$ & $0.10 \pm 0.04^{b}$ & $52.75 \pm 4.27^{b}$ & $1.60 \pm 0.27^{b}$ & $22.31 \pm 1.22^{\mathrm{a}}$ & $38.83 \pm 6.64^{b}$ & $2.59 \pm 0.33^{c}$ & $113.36 \pm 4.65^{b}$ & $44.32 \pm 5.48^{a}$ & $4.41 \pm 0.06^{\mathrm{a}}$ & $11.78 \pm 0.11^{c}$ \\
\hline & Jinzhong & $4.52 \pm 0.20^{\mathrm{b}}$ & $0.26 \pm 0.12^{\mathrm{a}}$ & $66.91 \pm 2.85^{\mathrm{a}}$ & $4.31 \pm 0.78^{\mathrm{a}}$ & $19.65 \pm 1.66^{\mathrm{b}}$ & $53.79 \pm 8.36^{\mathrm{a}}$ & $4.78 \pm 0.21^{b}$ & $143.50 \pm 10.02^{\mathrm{a}}$ & $30.10 \pm 2.68^{b}$ & $4.08 \pm 0.04^{b}$ & $14.14 \pm 0.63^{\mathrm{a}}$ \\
\hline & Linfen & $5.05 \pm 0.27^{\mathrm{a}}$ & $0.28 \pm 0.11^{\mathrm{a}}$ & $54.06 \pm 3.07^{b}$ & $3.54 \pm 0.52^{\mathrm{a}}$ & $22.49 \pm 2.39^{\mathrm{a}}$ & $40.58 \pm 5.57^{b}$ & $5.32 \pm 0.36^{\mathrm{a}}$ & $118.65 \pm 5.91^{b}$ & $22.39 \pm 2.17^{c}$ & $4.01 \pm 0.05^{\mathrm{c}}$ & $12.70 \pm 0.47^{b}$ \\
\hline
\end{tabular}


Table 2. Cont.

\begin{tabular}{|c|c|c|c|c|c|c|c|c|c|c|c|c|}
\hline Cultivars & $\begin{array}{l}\text { Growth } \\
\text { Sites }\end{array}$ & $\begin{array}{l}\text { Malic Acid } \\
\text { (mg/g) }\end{array}$ & $\begin{array}{c}\text { Ascorbic } \\
\text { Acid } \\
(\mathrm{mg} / \mathrm{g})\end{array}$ & $\begin{array}{c}\text { Fructose } \\
\text { (mg/g) }\end{array}$ & $\begin{array}{c}\text { Sorbitol } \\
\text { (mg/g) }\end{array}$ & $\begin{array}{c}\text { Glucose } \\
\text { (mg/g) }\end{array}$ & $\begin{array}{c}\text { Sucrose } \\
(\mathrm{mg} / \mathrm{g})\end{array}$ & $\begin{array}{c}\text { Total Acid } \\
\text { (mg/g) }\end{array}$ & $\begin{array}{l}\text { Total Sugar } \\
\text { (mg/g) }\end{array}$ & Sugar/Acid & $\mathrm{pH}$ & $\begin{array}{c}\text { Soluble } \\
\text { Solids } \\
\left({ }^{\circ} \text { Brix }\right)\end{array}$ \\
\hline \multirow{2}{*}{$\begin{array}{l}\text { Red General } \\
\quad \text { Fuji }\end{array}$} & Yuncheng & $3.21 \pm 0.21^{c}$ & $0.18 \pm 0.14^{\mathrm{a}}$ & $56.70 \pm 2.10^{c}$ & $2.81 \pm 0.41^{\mathrm{b}}$ & $25.00 \pm 1.23^{a}$ & $26.18 \pm 4.93^{b}$ & $3.39 \pm 0.23^{c}$ & $107.74 \pm 7.05^{b}$ & $31.97 \pm 4.03^{b}$ & $4.17 \pm 0.02^{\mathrm{a}}$ & $11.58 \pm 0.38$ \\
\hline & Linfen & $4.23 \pm 0.30^{\mathrm{a}}$ & $0.30 \pm 0.19^{a}$ & $69.12 \pm 2.98^{a}$ & $5.30 \pm 0.80^{a}$ & $19.01 \pm 1.81^{b}$ & $53.53 \pm 3.62^{\mathrm{a}}$ & $4.53 \pm 0.16^{\mathrm{a}}$ & $145.77 \pm 4.64^{\mathrm{a}}$ & $32.17 \pm 0.71^{b}$ & $4.00 \pm 0.06^{b}$ & $14.00 \pm 0.34$ \\
\hline \multirow{3}{*}{ Nagafu No. 2} & Yuncheng & $3.26 \pm 0.23^{c}$ & $0.33 \pm 0.08^{\mathrm{a}}$ & $61.11 \pm 1.06^{b}$ & $5.77 \pm 1.04^{b}$ & $32.30 \pm 1.83^{a}$ & $31.92 \pm 3.62^{b}$ & $3.60 \pm 0.25^{c}$ & $131.10 \pm 2.66^{b}$ & $36.56 \pm 2.07^{\mathrm{a}}$ & $4.31 \pm 0.02^{\mathrm{a}}$ & $13.46 \pm 0.59^{b}$ \\
\hline & Jinzhong & $5.01 \pm 0.60^{\mathrm{a}}$ & $0.28 \pm 0.09^{a}$ & $74.04 \pm 2.02^{\mathrm{a}}$ & $7.68 \pm 1.23^{a}$ & $21.42 \pm 2.09^{b}$ & $55.71 \pm 9.48^{\mathrm{a}}$ & $5.29 \pm 0.67^{\mathrm{a}}$ & $157.81 \pm 10.23^{a}$ & $30.32 \pm 5.10^{\mathrm{a}}$ & $4.01 \pm 0.02^{b}$ & $15.48 \pm 0.75$ \\
\hline & Linfen & $4.25 \pm 0.48^{\mathrm{b}}$ & $0.25 \pm 0.05^{\mathrm{a}}$ & $64.37 \pm 3.46^{b}$ & $7.53 \pm 1.07^{a}$ & $23.64 \pm 2.52^{b}$ & $63.04 \pm 7.18^{\mathrm{a}}$ & $4.50 \pm 0.51^{\mathrm{b}}$ & $158.00 \pm 6.64^{\mathrm{a}}$ & $35.36 \pm 3.27^{\mathrm{a}}$ & $4.04 \pm 0.09^{b}$ & $15.06 \pm 0.47^{\circ}$ \\
\hline \multirow{2}{*}{ Huimin Fuji } & Yuncheng & $3.03 \pm 0.17^{\mathrm{a}}$ & $0.19 \pm 0.07^{\mathrm{a}}$ & $55.46 \pm 3.93^{\mathrm{a}}$ & $3.78 \pm 0.32^{\mathrm{a}}$ & $28.49 \pm 3.11^{\mathrm{a}}$ & $35.53 \pm 7.46^{\mathrm{a}}$ & $3.22 \pm 0.20^{\mathrm{a}}$ & $120.93 \pm 5.68^{a}$ & $37.67 \pm 2.81^{\mathrm{a}}$ & $4.30 \pm 0.02^{\mathrm{a}}$ & $12.80 \pm 0.34$ \\
\hline & Linfen & $3.34 \pm 0.32^{\mathrm{a}}$ & $0.18 \pm 0.09^{\mathrm{a}}$ & $57.44 \pm 3.58^{\mathrm{a}}$ & $2.87 \pm 0.74^{\mathrm{b}}$ & $23.28 \pm 1.97^{b}$ & $27.25 \pm 9.40^{\mathrm{a}}$ & $3.52 \pm 0.37^{\mathrm{a}}$ & $110.84 \pm 11.07^{\mathrm{a}}$ & $31.75 \pm 4.70^{\mathrm{b}}$ & $4.16 \pm 0.06^{b}$ & $11.60 \pm 1.08$ \\
\hline \multirow{2}{*}{$\begin{array}{c}\text { Yantai Fuji } \\
\text { No. } 3\end{array}$} & Yuncheng & $2.39 \pm 0.07^{b}$ & $0.09 \pm 0.04^{\mathrm{b}}$ & $57.44 \pm 0.75^{b}$ & $3.27 \pm 0.13^{b}$ & $30.82 \pm 0.56^{\mathrm{a}}$ & $28.46 \pm 2.82^{b}$ & $2.47 \pm 0.11^{\mathrm{b}}$ & $119.98 \pm 3.74^{b}$ & $48.53 \pm 1.22^{\mathrm{a}}$ & $4.24 \pm 0.02^{\mathrm{a}}$ & $12.82 \pm 0.08$ \\
\hline & Linfen & $3.59 \pm 0.47^{\mathrm{a}}$ & $0.37 \pm 0.09^{\mathrm{a}}$ & $65.34 \pm 2.49^{a}$ & $3.99 \pm 0.47^{\mathrm{a}}$ & $29.11 \pm 2.15^{a}$ & $37.65 \pm 6.69^{a}$ & $3.96 \pm 0.53^{\mathrm{a}}$ & $136.08 \pm 5.68^{a}$ & $34.86 \pm 5.04^{b}$ & $4.07 \pm 0.06^{b}$ & $14.76 \pm 0.34$ \\
\hline \multirow[b]{2}{*}{ Qinguan } & Yuncheng & $2.70 \pm 0.08^{b}$ & $0.45 \pm 0.10^{\mathrm{a}}$ & $65.78 \pm 1.59^{a}$ & $8.83 \pm 0.51^{\mathrm{a}}$ & $35.50 \pm 0.67^{a}$ & $41.01 \pm 7.28^{\mathrm{a}}$ & $3.15 \pm 0.17^{b}$ & $149.12 \pm 5.97^{\mathrm{a}}$ & $47.47 \pm 4.34^{\mathrm{a}}$ & $4.48 \pm 0.03^{\mathrm{a}}$ & $15.86 \pm 0.13$ \\
\hline & Linfen & $3.30 \pm 0.25^{\mathrm{a}}$ & $0.26 \pm 0.19^{b}$ & $51.84 \pm 0.61^{\mathrm{b}}$ & $5.47 \pm 0.85^{\mathrm{b}}$ & $23.39 \pm 2.34^{\mathrm{b}}$ & $43.43 \pm 6.82^{\mathrm{a}}$ & $3.56 \pm 0.41 \mathrm{ab}$ & $122.29 \pm 6.08^{\mathrm{b}}$ & $34.84 \pm 4.91^{\mathrm{b}}$ & $4.30 \pm 0.08^{\mathrm{b}}$ & $12.34 \pm 0.15^{b}$ \\
\hline \multicolumn{13}{|c|}{ Comparison between Commercial Cultivars and Crabapples (Malus genus) } \\
\hline $\begin{array}{l}\text { M. pumila } \\
\text { 'Saiwaihong' }\end{array}$ & Linfen & $4.78 \pm 0.19^{c}$ & $0.96 \pm 0.06^{\mathrm{a}}$ & $49.62 \pm 0.91^{\mathrm{c}}$ & $12.24 \pm 0.14^{c}$ & $30.04 \pm 0.61^{\mathrm{c}}$ & $76.88 \pm 3.16^{\mathrm{a}}$ & $5.74 \pm 0.23^{c}$ & $168.78 \pm 4.65^{\mathrm{a}}$ & $29.44 \pm 0.78^{b}$ & $3.98 \pm 0.01^{\mathrm{b}}$ & $17.46 \pm 0.17$ \\
\hline $\begin{array}{l}\text { M. prunifolia } \\
\text { (Willd.) } \\
\text { Borkh. }\end{array}$ & Jinzhong & $9.72 \pm 0.31^{\mathrm{b}}$ & $0.65 \pm 0.15^{b}$ & $71.81 \pm 1.55^{\mathrm{a}}$ & $15.70 \pm 0.43^{\mathrm{a}}$ & $54.11 \pm 1.81^{\mathrm{a}}$ & $21.07 \pm 2.37^{c}$ & $10.36 \pm 0.45^{b}$ & $162.7 \pm 4.86^{\mathrm{a}}$ & $15.71 \pm 0.37^{\mathrm{c}}$ & $3.42 \pm 0.01^{\mathrm{c}}$ & $20.92 \pm 0.19^{\circ}$ \\
\hline $\begin{array}{c}\text { M. } \\
\text { micromalus } \\
\text { Makino }\end{array}$ & Jinzhong & $18.73 \pm 0.28^{\mathrm{a}}$ & $0.60 \pm 0.11^{b}$ & $61.25 \pm 1.01^{b}$ & $12.63 \pm 0.14^{b}$ & $44.11 \pm 0.98^{b}$ & $17.00 \pm 0.97^{c}$ & $19.33 \pm 0.34^{\mathrm{a}}$ & $134.98 \pm 1.27^{b}$ & $6.98 \pm 0.09 \mathrm{~d}$ & $3.13 \pm 0.00^{d}$ & $19.38 \pm 0.08^{b}$ \\
\hline $\begin{array}{l}\text { M. domestica } \\
\text { Borkh. } \\
\text { (cultivated) * }\end{array}$ & $\begin{array}{l}\text { Yuncheng } \\
\text { Jinzhong } \\
\text { Linfen }\end{array}$ & $3.19 \pm 0.95^{\mathrm{d}}$ & $0.20 \pm 0.13^{c}$ & $62.63 \pm 6.79^{b}$ & $4.77 \pm 2.27^{\mathrm{d}}$ & $23.54 \pm 5.69^{d}$ & $40.71 \pm 12.98^{b}$ & $3.39 \pm 1.02^{d}$ & $131.65 \pm 15.93^{b}$ & $42.14 \pm 12.60^{a}$ & $4.23 \pm 0.17^{\mathrm{a}}$ & $13.51 \pm 1.38^{\circ}$ \\
\hline
\end{tabular}

The letters $\mathrm{a}, \mathrm{b}, \mathrm{c}$, and d marked the significant statistical differences $(p<0.05)$ within each comparison. ${ }^{*}$ Values of contents in M. domestica Borkh. (cultivated) was the average of all the cultivated apples. 

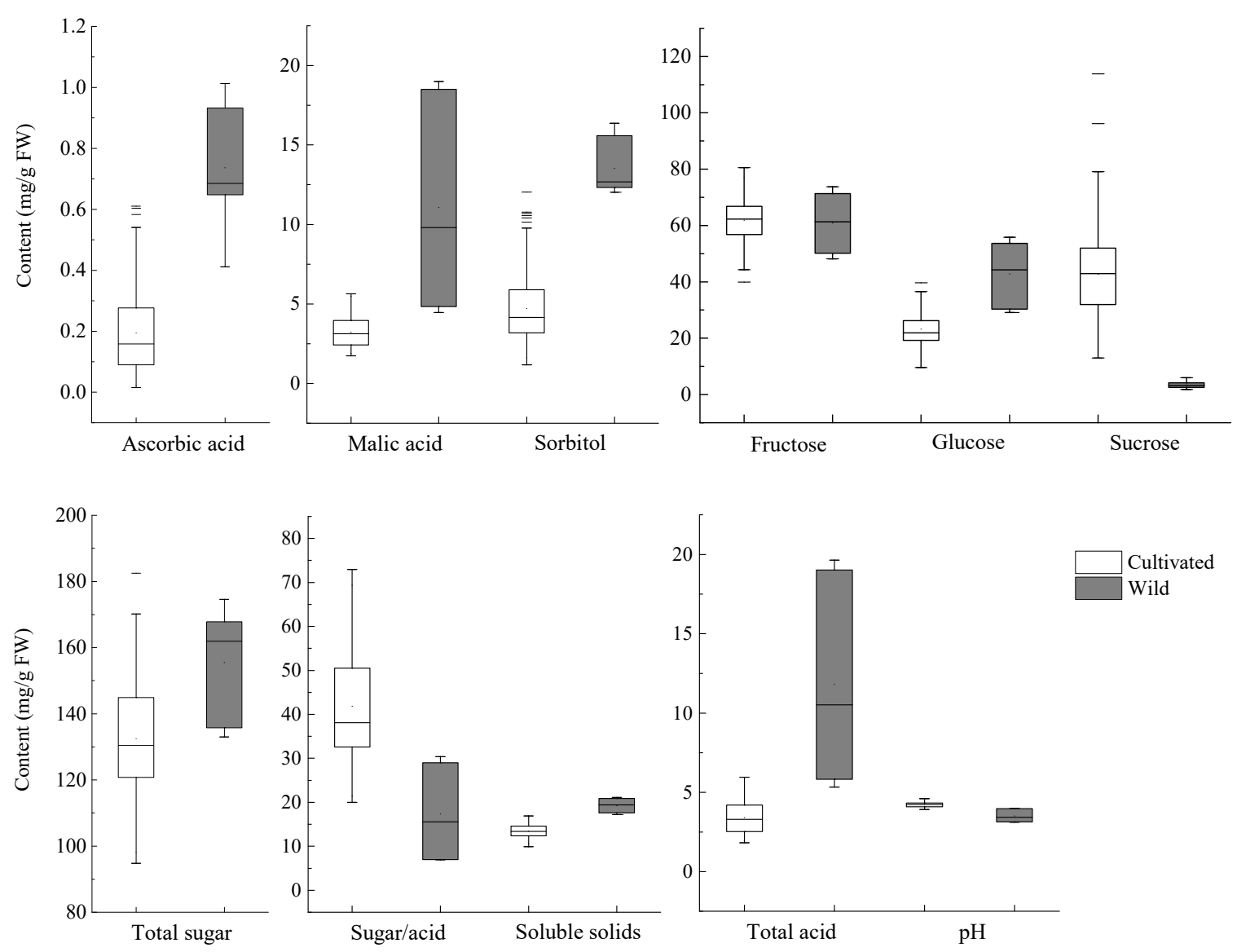

Figure 1. Range and distribution of sugars and acids in cultivated and wild apples. The horizontal lines in the interior of the box are the median values. The height in the box is equal to the interquartile distance, indicating the distribution for $50 \%$ of the data. Approximately $99 \%$ of samples fall inside the whiskers and the samples outside these whiskers are indicated by horizontal lines.

Ascorbic acid is an important antioxidant in apples. The ascorbic acid content in most of the cultivated apples ranged from 0.1 to $0.4 \mathrm{mg} / \mathrm{g}$ f.w., whereas the levels in three wild forms were higher $(0.6-1 \mathrm{mg} / \mathrm{g}$, respectively). Among commercial cultivars, the highest ascorbic acid content was found in 'Qiufu No. $1^{\prime}$ cultivated in Yuncheng $(0.45 \mathrm{mg} / \mathrm{g}$ f.w.) as well as 'Yantai Fuji No. $3^{\prime}$ and 'Zhongqiuwang' harvested from Linfen $(0.37 \mathrm{mg} / \mathrm{g}$ f.w.). Kumar et al. [37] reported ascorbic acid content to be 0.22 and $0.29 \mathrm{mg} / \mathrm{g}$ in the fresh fruits of 'Golden Delicious' grown at altitudes of 1400 and $1800 \mathrm{~m}$, respectively, which is close to the levels found in the fruits of the same cultivar grown in Jinzhong $(800-1000 \mathrm{~m}$, $0.26 \mathrm{mg} / \mathrm{g}$ ) and Linfen $(900-1200 \mathrm{~m}, 0.28 \mathrm{mg} / \mathrm{g}$ ) in our present study. It is noteworthy that 'Saiwaihong' has the highest content of ascorbic acid $(0.96 \mathrm{mg} / \mathrm{g})$ among all the samples studied. A previous study reported ascorbic acid contents between 0.029 and $0.256 \mathrm{mg} / \mathrm{g}$ FW in whole fruits of 30 ancient cultivars of Belgian apples [38]. Ascorbic acid mainly is located in the peel of apples [39]. Bassi and colleagues reported that the content of ascorbic acid in pulp varied in the range of $0.001-0.139 \mathrm{mg} / \mathrm{g}$ (FW) in 64 different apple cultivars, while the content in the peel was $0.049-0.521 \mathrm{mg} / \mathrm{g}$ (FW) [40]. It is noteworthy that the ascorbic acid contents in whole wild apples of 'Saiwaihong' were higher than the contents reported in the pulp and peel of 64 commercial apple cultivars. All figures and tables should be cited in the main text as Figure 1, Table 1, etc. 


\subsection{Comparison between Commercial Cultivars and Wild Apples}

In this study, we investigated the content of sugars and acids in 17 cultivated and 3 wild species (Table 2 and Figure 1). In general, fructose was the most abundant among sugar in cultivated and wild apples, followed by sucrose and glucose in cultivated apples whilst followed by glucose and sucrose in wild apples. A previous study showed that the average concentrations of sucrose were 2-3 times higher than that of glucose in mature fruits of 321 apple cultivars, while the average contents of glucose were over 3 times higher than that of sucrose in 43 forms of wild apples [19]. This is likely the result of continuous selection since the sweetness of sucrose is higher than that of glucose. In our study, the sorbitol contents in the fruits of three wild forms were over $12 \mathrm{mg} / \mathrm{g}$, being much higher than the levels in the commercial cultivars $(p<0.01)$. Moreover, the three wild forms had higher soluble solid matters (above 17\%) in the juice, compared with the commercially cultivated apples (average 13.5\%, $p<0.01$ ).

In addition, cultivated apples had lower content of ascorbic acid and malic acid, higher $\mathrm{pH}$ values, and higher sugar/acid ratios, compared to wild apples $(p<0.01)$. It has been shown that Asian consumers prefer very sweet apples with low intensity of acidic flavor [41]. The total acid content showed a significant difference between wild apple species and the commercially cultivated varieties $(p<0.01)$, whereas no significant difference in the total concentration of sugars was observed between M. micromalus Makino and cultivated apples. Thus, low content of acids has likely been a key criterion for selection during apple breeding. Malic acid is the major contributor to the acidity of apples. High sugar/acid ratio and low content of malic acid are often directly associated with high intensities of the sweetness of apple fruits [18]. The fruits of the three wild apple species contained more malic acid $(9.7 \mathrm{mg} / \mathrm{g}, 18.7 \mathrm{mg} / \mathrm{g}$, and $4.78 \mathrm{mg} / \mathrm{g}$ fresh weight, respectively) than the commercial cultivars (average $3.19 \mathrm{mg} / \mathrm{g}, p<0.01$ ). This was in agreement with a previous study, where wild apples were reported to have an average content of malic acid over 2.2 times higher than the levels found in the cultivated apples [19]. M. pumila 'Saiwaihong' contained malic acid at a level of close to $5 \mathrm{mg} / \mathrm{g}$, which is within the range of the content determined in commercially cultivated apples. It is worth noting that M. pumila 'Saiwaihong' is a wild apple in the traditional sense, but it has been approved as a variety in 2018 for commercial cultivation in China. The sugar/acid ratios in the wild apples were significantly lower than the values of the cultivated apples. Especially, the sugar/acid ratio of two wild types (M. prunifolia (Willd.) Borkh. and M. micromalus Makino) were 15.71 and 6.98 , respectively.

It has been reported that cultivated apples are characterized by larger fruit size and higher content of sugars when compared to the wild forms [35,42]. Nevertheless, in our study, no clear differences were found in the total sugar content between the commercial cultivars and the wild forms. Therefore, our study confirmed Ma's finding, suggesting that fruit acidity, instead of sweetness, has undergone selection during apple domestication [19]. The higher soluble solids of the wild apples compared to the commercial cultivars in this study were mostly due to their higher contents of malic acid and ascorbic acid, not because of differences in sugar contents.

As expected, the aqueous extracts of the fruits of the wild species had lower $\mathrm{pH}$ values (below 4) due to the higher total content of acids compared with the cultivated apples.

To further demonstrate the difference between the commercially cultivated and wild apples, a principal component analysis (PCA) model was constructed (Figure 2). The first two principal components (PCs) explained $73 \%$ of the variance of the data. In the scores plot PCA (Figure 2a), the three wild species were clearly separated from the cultivated apples. The closer the samples are located on the plot, the more similar the compositional characteristics of the samples. In the PCA loadings plot (Figure 2b), the PC1 (53\%) represented the major components of acids (malic acid, total acid, ascorbic acid), some sugars (glucose and sorbitol), and soluble solids on the positive side, $\mathrm{pH}$ and sugar/acid on the negative side. The three wild species had similar characteristics highly explained by PC1 by relatively high contents of ascorbic acid, total acids, glucose, sorbitol, and soluble solids, 
but low values of $\mathrm{pH}$ and sugar/acid ratio among the samples investigated. In contrast, the cultivated apples located on the negative side of PC1 show the opposite characteristics. The PC2, explaining $20 \%$ of the variance, represented the content of sucrose and the total sugar content. The PC2 separated the three wild forms based on their sugar content, especially the content of sucrose in the order: M. pumila 'Saiwaihong' > M. prunifolia (Willd.) Borkh. > M. micromalus Makino.

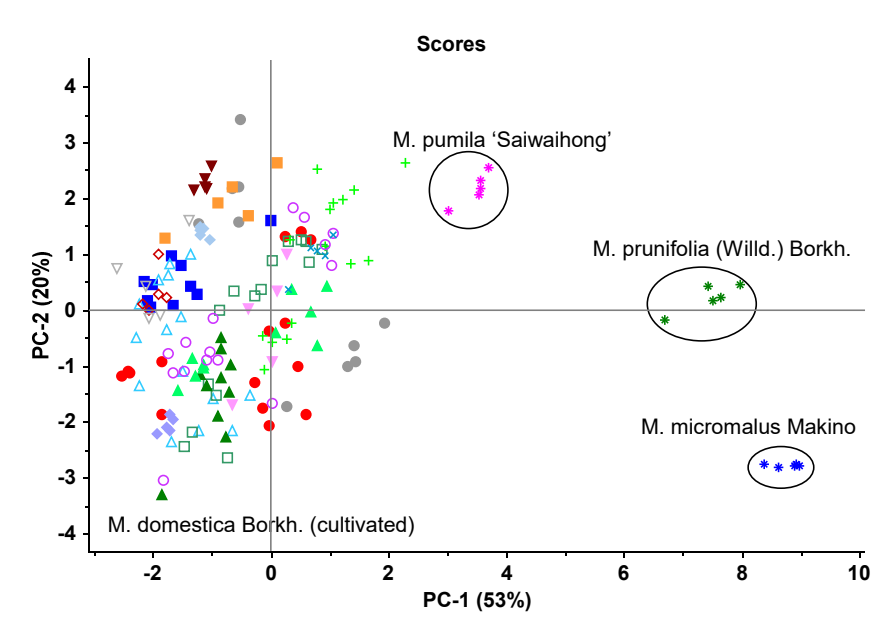

(a)

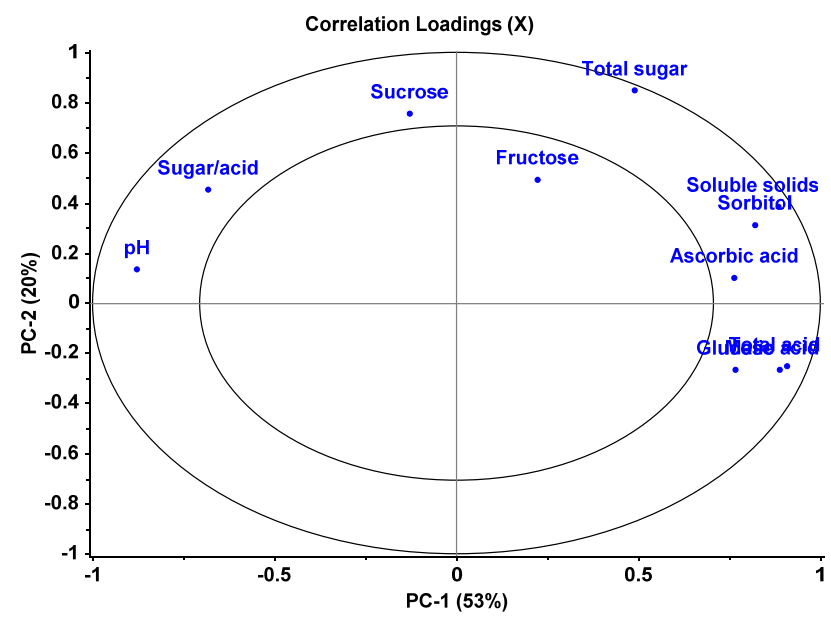

(b)

Figure 2. PCA model of cultivated and wild apples: (a) Scores plot; (b) Loadings plot.

\subsection{Comparison among Commercial Cultivars within Each Growth Region}

Due to the impact of the growth environment on fruit quality, it is important to compare the fruit composition among cultivars grown in the same regions. Separate PCA models were constructed to demonstrate the compositional difference among different cultivars grown in the same region (Figure 3). Among the cultivars grown in Yuncheng (Figure 3a), 'Qinguan' was characterized by high content of total sugars, fructose, sorbitol, ascorbic acid, and soluble solids, whereas 'Xinshiji' stood out due to the high content of malic acid and ascorbic acid. 'Gala' clearly differed from other cultivars by high sugar/acid ratio. The lowest sugar/acid ratios were found in the fruits of the cultivars 'Xinshiji' (27.6), 'Starkrimson' (28.1), and 'Red General Fuji' (32.0) (Table 2). Detailed statistical comparisons in each of the compositional parameters among the cultivars grown in Yuncheng are presented in Table S1.

Among the cultivars grown in Linfen (Figure 3b), 'Naga Fu No. 2' had higher content of sugars (fructose, sucrose, and total sugars) and soluble solids, whereas 'Golden Delicious' had high content of malic acid, ascorbic acid, and total acids. However, 'Starkrimson' was clearly separated from other cultivars by high sugar/acid ratio. This was clearly in contrast with the situation in Yuncheng. Detailed statistical comparisons in each of the compositional parameters among the cultivars grown in Linfen are presented in Table S2.

Within Jinzhong region (Figure 3c), 'Liuyuehong' and 'Xiali' were characterized by a higher sugar/acid ratio compared to other cultivars. 'Starkrimson' and 'Starking Delicious' were also associated with high sugar/acid ratios. Similar to the situation in Linfen, 'Naga Fu No. 2' had higher content of sugars (fructose, sucrose, and total sugars) and soluble solids, whereas 'Golden Delicious' had high content of malic acid, ascorbic acid, and low sugar/acid ratio. Detailed statistical comparisons in each of the compositional parameters among the cultivars grown in Jinzhong are presented in Table S3. 

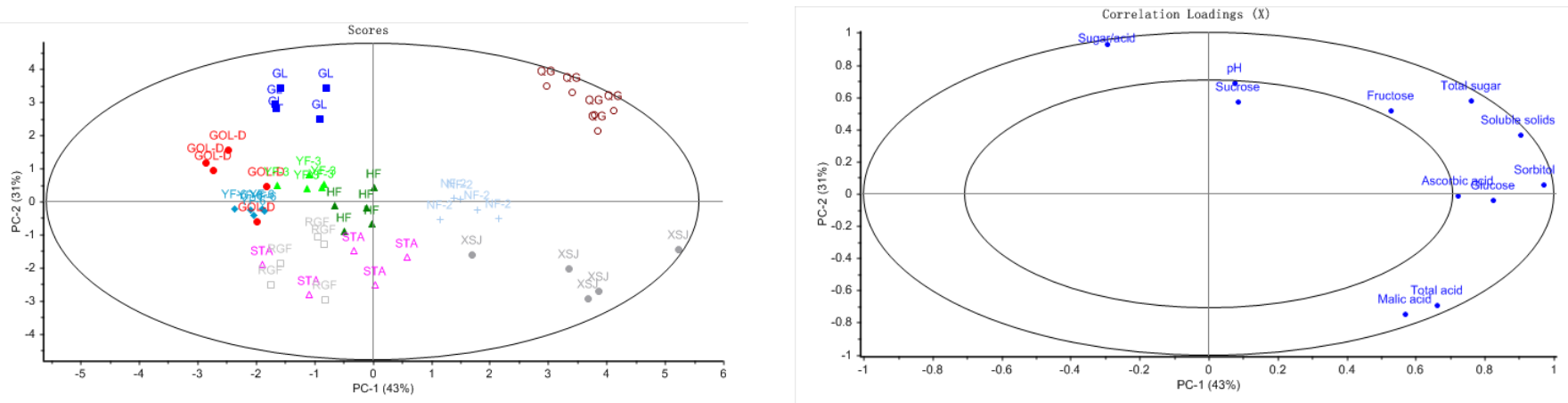

(a)
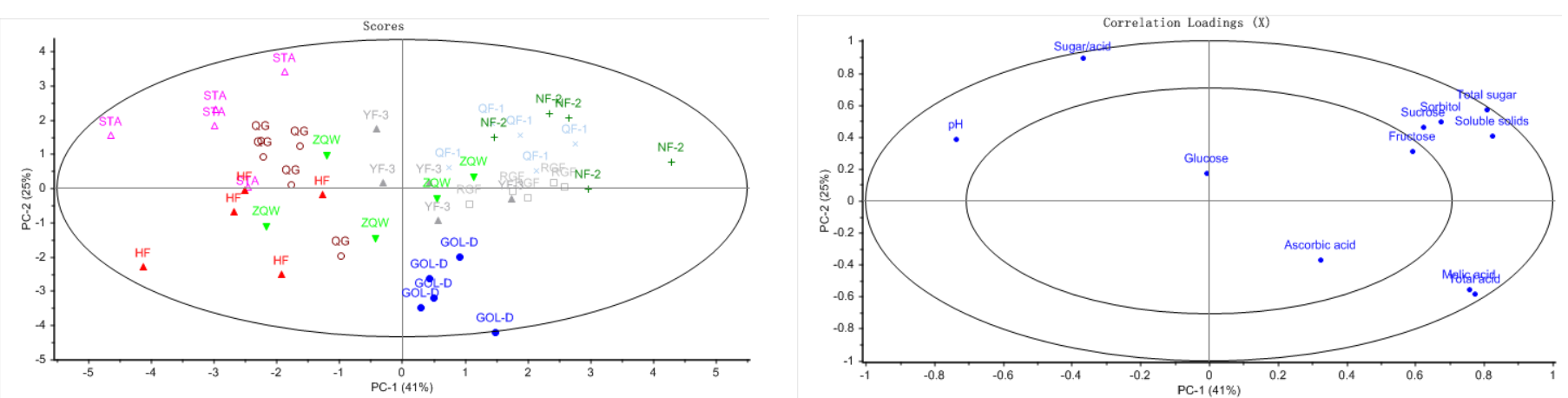

(b)
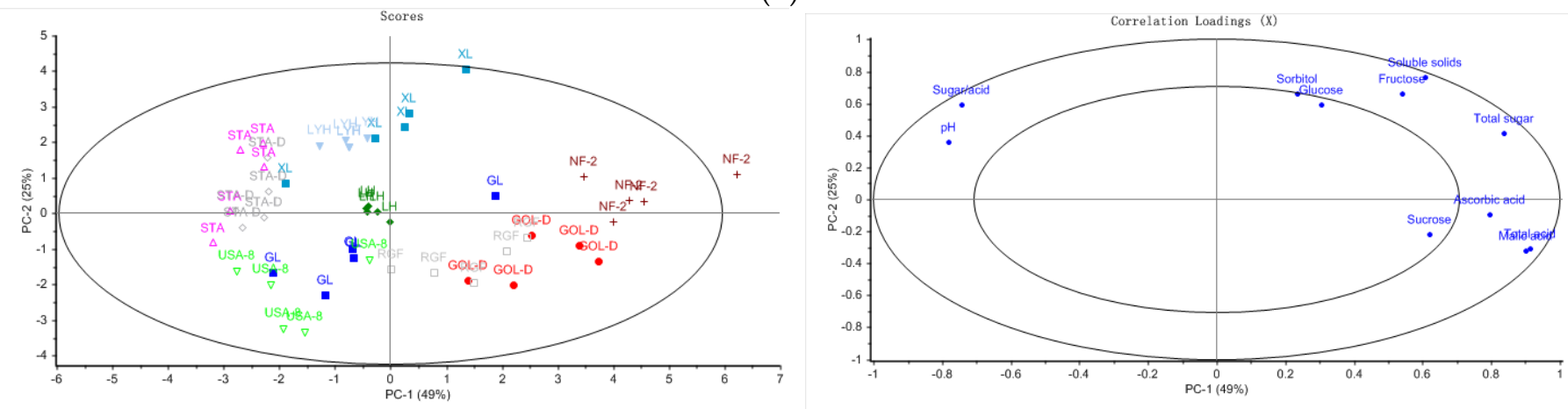

(c)

Figure 3. PCA models and loading plots of cultivars within each growth region. (a) Yuncheng. (b) Linfen. (c) Jinzhong.

\subsection{Hierarchical Cluster Analysis of Cultivated Apples Based on Sugars and Acids Subsection}

In view of the differences in sugars and acids in cultivated apples, we performed a hierarchical cluster analysis to identify 17 cultivated apples (a total of 31 samples), taking into account all the variables (Figure 4). The optimum number of clusters identified for analysis was 4 , which was grouped by the elbow method. Cluster 1 (blue lines) included 14 samples, cluster 2 (red lines) included 9 samples, cluster 3 (green lines) included 7 samples, while 'Xinshiji' collected from Yunnan Province was clustered into a separate group (cluster 4). 


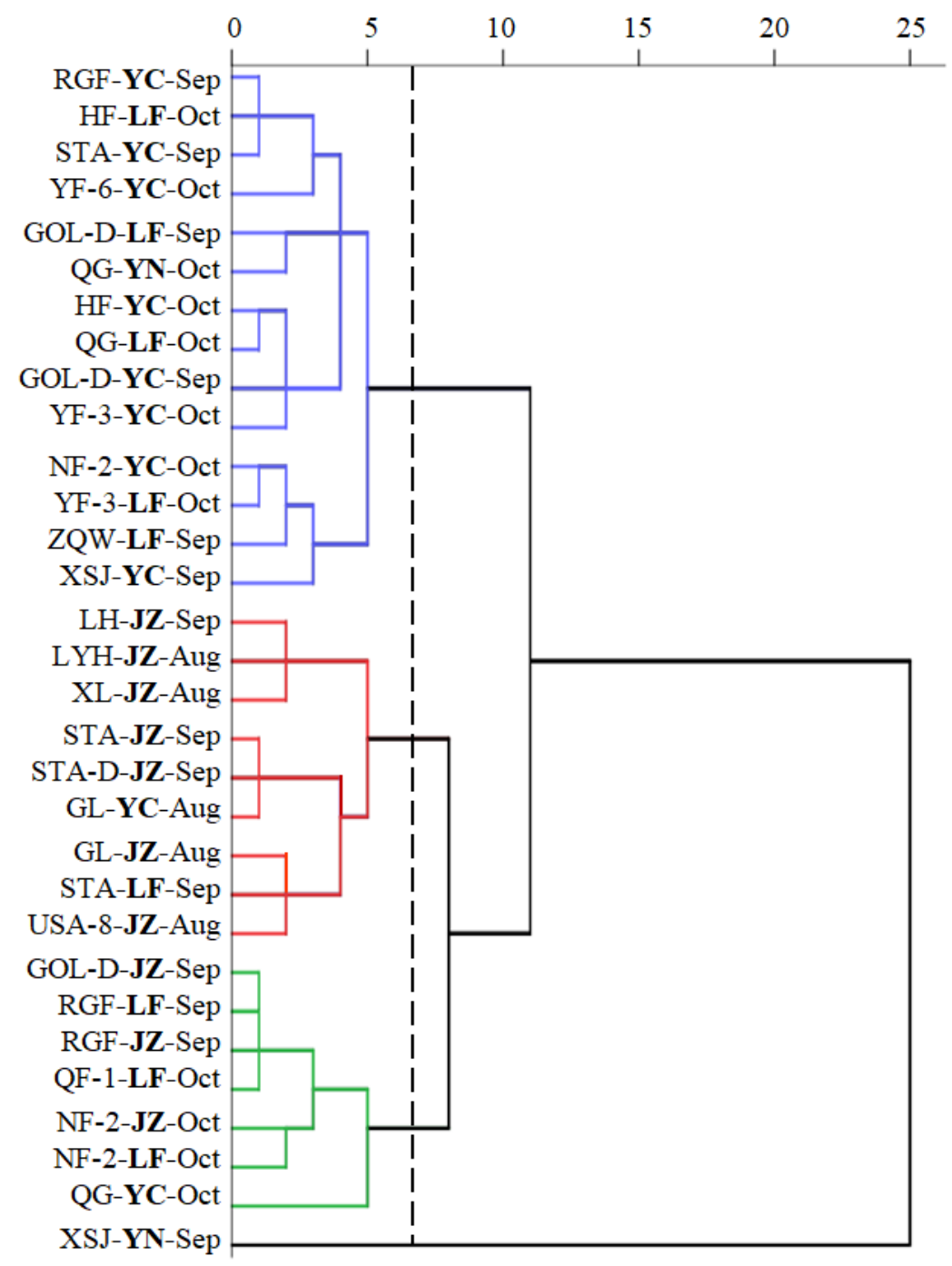

Figure 4. Hierarchical clustering analysis of sugars and acids of the 17 cultivated apples (A total of 31 apple samples studied). Serial nomenclature consists of the abbreviation of the cultivated apples, growth sites and ripening times. The abbreviation of cultivated apples is in Table 1. YC is Yuncheng City, Shanxi Province, JZ is Jinzhong City, Shanxi Province, LF is Linfen City, Shanxi Province and YN is Yunnan Province. Aug is August, Sep is September and Oct is October. Blue lines refer to Cluster 1, Red lines refer to Cluster 2, Green lines refer to Cluster 3, and the black line from 'XSJ-YN-Sep' refers to Cluster 4 .

Within each cluster, cultivars with similar profiles of sugars and acids were grouped together into smaller subgroups. For example, within cluster 2, 'Lihong', 'Liuyuehong', 'Xiali' formed a subgroup characterized by high sugar contents and high sugar/acid ratios; the second and the third subgroups consisted of 'Starkrimson' and 'Gala' cultivated in Yuncheng and Jinzhong, as well as 'Starking Delicious' and 'USA-8'. It is important to notice that the cultivated apples of the same cultivars were grouped into different clusters or sub-groups, depending on the growth sites. Especially, the samples of 'Starkrimson', 'Golden Delicious', 'Red General Fuji' and 'Nagafu No. 2' collected from three growth sites and the samples of 'Xinshiji' and 'Qinguan' collected from two growth sites were separated into two clusters, which underlined the impacts of environmental conditions on the apple quality. The impact of ripening time and growth site will be discussed in the following sections.

Furthermore, it is interesting to note that all the apple samples of the early-ripening cultivars harvested in August were clustered into cluster 2, whereas the samples ripening 
and harvested in October were clustered into cluster 1 and cluster 3. All clusters included samples ripened and harvested in September. The possible link between the ripening time and the content of the sugars and acids in apple fruits was investigated using Principal Component Analysis (PCA) and Pearson correlation coefficients, which are presented and discussed in Section 3.4.

\subsection{Association of Content of Sugars and Acids with Ripening Time of Cultivated Apples}

Figure 5 shows the PCA plot for the 17 cultivars harvested in August, September, and October, representing early, medium, and late-ripening groups, respectively. The first three principal components (PCs) explained $80 \%$ of the variance of the data. In the PCA scores plot, apple samples harvested in August and apple samples harvested in October were clearly divided into two groups. The samples harvested in August were distributed on the left, which were characterized as relatively high values of $\mathrm{pH}$ and sugar/acid as well as higher content of fructose. In contrast, the samples harvested in October located on the right and were characterized by higher contents of acids (ascorbic acid, malic acid and total acid) and glucose. The samples harvested in September were scattered across the PCA plot overlapping with the samples of the previous two groups.

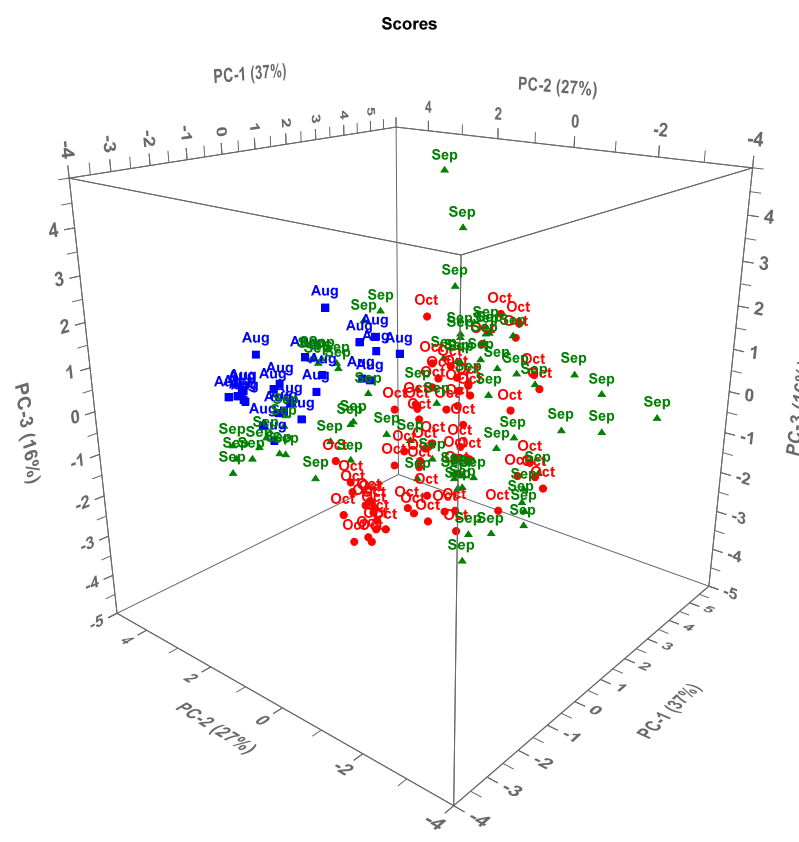

(a)

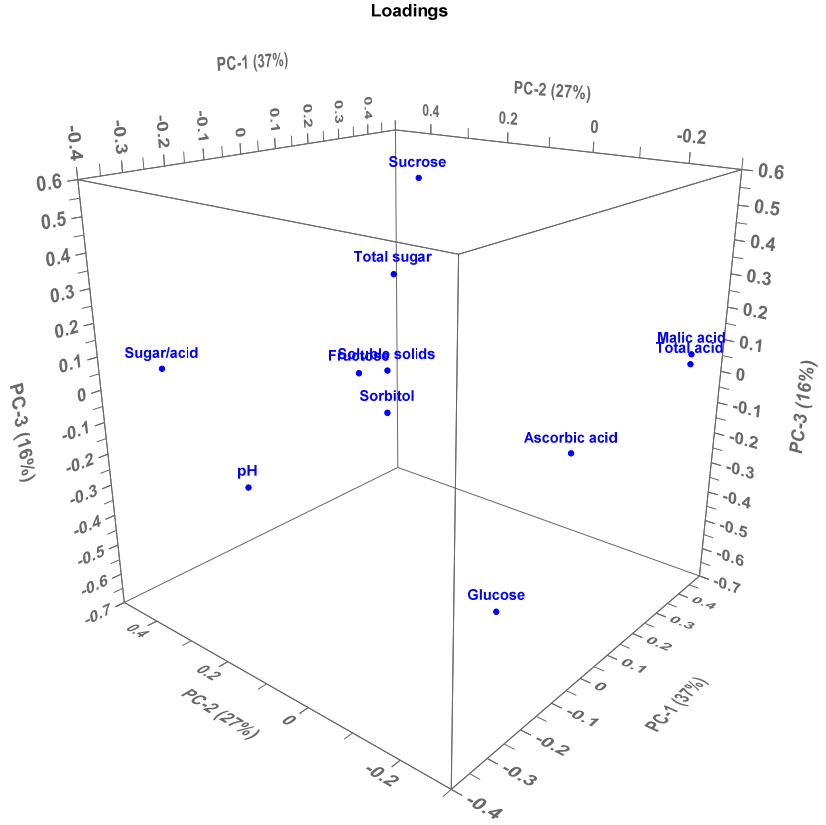

(b)

Figure 5. PCA model of cultivated apples by ripening time: (a) Scores plot; (b) Loadings plot. Square with Aug logo in blue font represents samples collected at August, Positive triangle with Sep logo in green font represents samples collected at September, and Dot with Oct logo in red font represents samples collected at October.

For further understanding, the Pearson correlation coefficients were applied to study the correlation between the composition of apples and the ripening time (Table 3). Late ripening time was positively correlated with total acid $(\mathrm{r}=0.358, p<0.01)$, malic acid $(\mathrm{r}=0.345, p<0.01)$, ascorbic acid $(\mathrm{r}=0.273, p<0.01)$ and glucose $(\mathrm{r}=0.544, p<0.01)$, but negatively correlated with fructose $(\mathrm{r}=-0.199, p<0.05)$, sucrose $(\mathrm{r}=-0.199, p<0.05)$ and sugar/acid $(r=-0.503, p<0.01)$.

The results of PCA analysis and Pearson correlation coefficients indicated that the apple samples of early-ripening cultivars harvested in August had higher sugar content, especially sucrose and fructose, whereas the samples of the late-ripening cultivars harvested in October had a higher content of acid and glucose. 
Table 3. Pearson's correlation coefficients between altitude and ripening time and 11 indicators of apple cultivars.

\begin{tabular}{ccccccccccccc}
\hline & & $\begin{array}{c}\text { Malic } \\
\text { Acid }\end{array}$ & $\begin{array}{c}\text { Ascorbic } \\
\text { Acid }\end{array}$ & Fructose & Sorbitol & Glucose & Sucrose & $\begin{array}{c}\text { Total } \\
\text { Acid }\end{array}$ & $\begin{array}{c}\text { Total } \\
\text { Sugar }\end{array}$ & $\begin{array}{c}\text { Sugar } \\
\text { /Acid }\end{array}$ & $\begin{array}{c}\text { pH } \\
\text { Soluble } \\
\text { Solids }\end{array}$ \\
\hline Ripening & $\mathrm{r}$ & $0.345^{* *}$ & $0.273^{* *}$ & $-0.199^{*}$ & 0.057 & $0.544^{* *}$ & $-0.199^{*}$ & $0.358^{* *}$ & -0.074 & $-0.503^{* *}$ & -0.128 & -0.014 \\
time & $p$ & $<0.001$ & $<0.001$ & 0.013 & 0.480 & $<0.001$ & 0.013 & $<0.001$ & 0.361 & $<0.001$ & 0.111 & 0.860 \\
\hline \multirow{2}{*}{ Altitude } & $\mathrm{r}$ & $0.342^{* *}$ & 0.082 & -0.071 & -0.014 & $-0.444^{* *}$ & $0.517^{* *}$ & $0.331^{* *}$ & $0.284^{* *}$ & $-0.218^{* *}$ & $-0.312^{* *}$ & 0.051 \\
& $p$ & $<0.001$ & 0.308 & 0.379 & 0.867 & $<0.001$ & $<0.001$ & $<0.001$ & $<0.001$ & 0.006 & $<0.001$ & 0.532 \\
\hline
\end{tabular}

${ }^{*}: p \leq 0.05 ; * *: p \leq 0.01$.

\subsection{Effect of Latitude of Growth Site on Sugars and Acids of Cultivated Apples}

PCA plots were constructed to further investigate the effect of growth sites on apple composition of each of the four cultivars, 'Starkrimson', 'Golden Delicious', 'Red General Fuji' and 'Nagafu No. 2' collected from three growth locations at different altitudes: Yuncheng (low altitude 400-800 m), Jinzhong (middle altitude 800-1000 m), and Linfen (high altitude 900-1200 m). In the PCA scores plot, the samples were clearly grouped according to the growth sites, and the samples from Yuncheng were further separated from the samples from the other two growth regions. As shown in PCA and the loadings plots, for the three cultivars 'Golden Delicious' (Figure 6a), 'Red General Fuji' (Figure 6b), and 'Nagafu No. 2' (Figure 6c), the samples from Yucheng (low altitude) were characterized by higher content of glucose and higher values of $\mathrm{pH}$ and sugar/acid ratio, but lower contents of malic acid and ascorbic acid, in comparison with the samples of the same cultivars harvested from Jinzhong (middle altitude) and Linfen (high altitude). For 'Starkrimson', the sample from Yuncheng was richer in malic acid and ascorbic acid than the samples from the two other locations (Figure 6d). For all the varieties, the samples from Yuncheng were clearly characterized by a lower level of sucrose and total content of sugars compared to the samples from Jinzhong and Linfen.
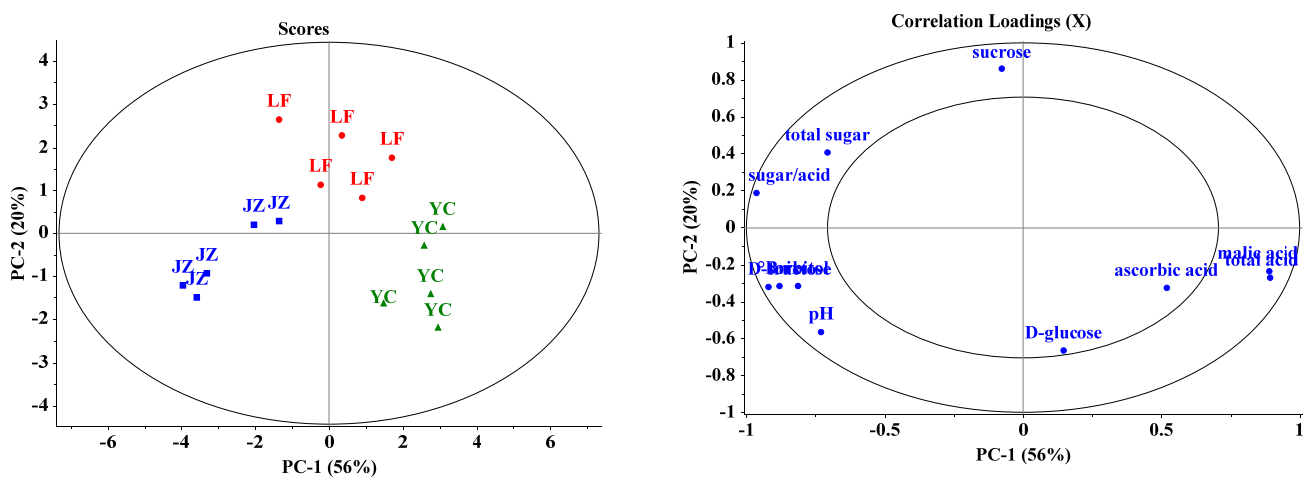

(a)
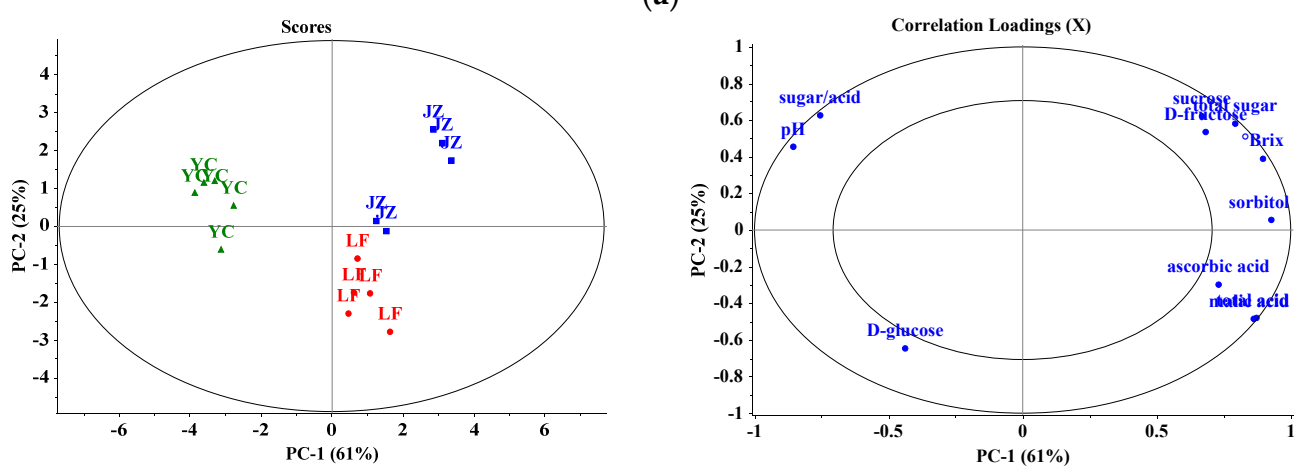

(b)

Figure 6. Cont. 

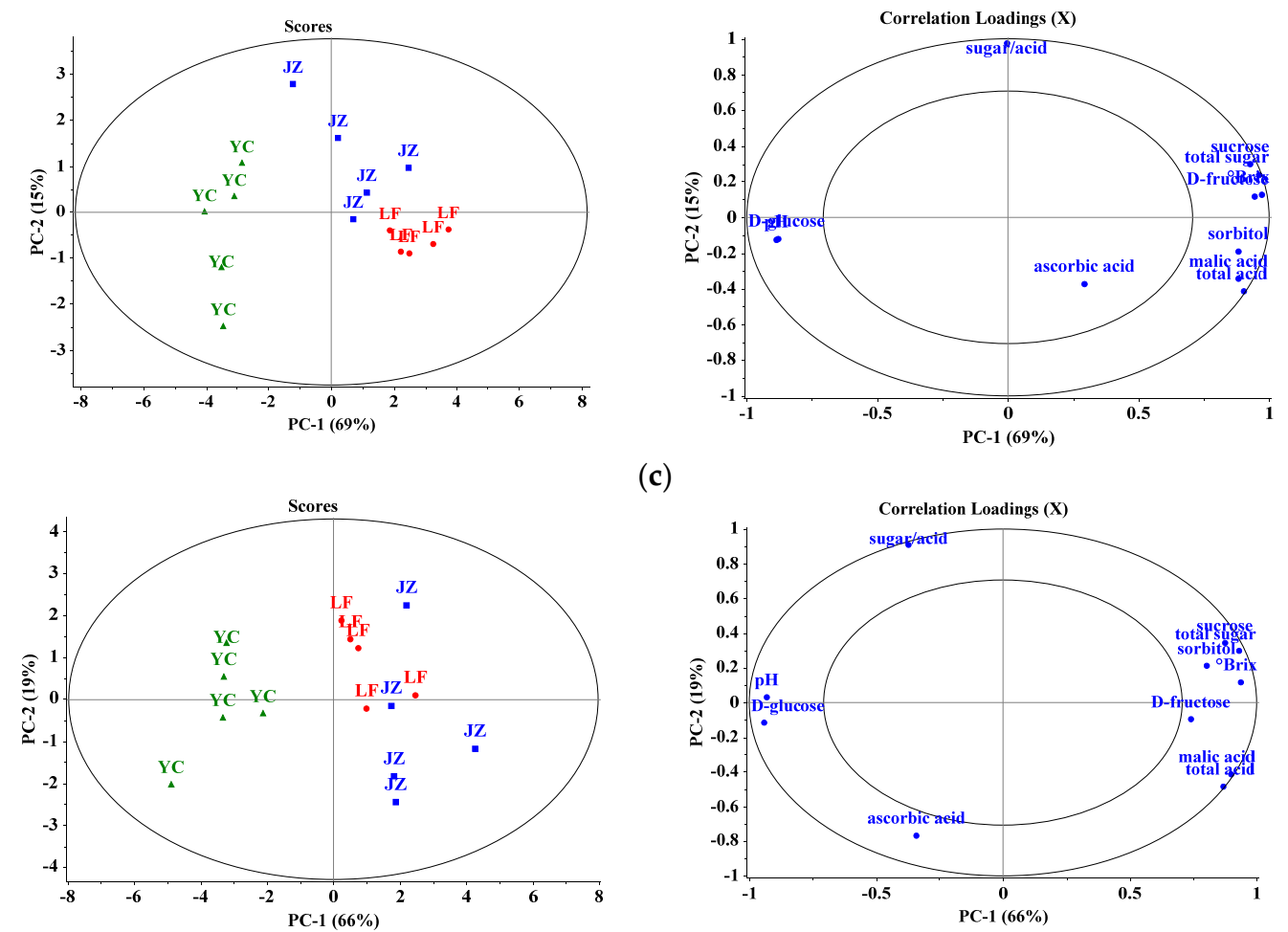

(c)

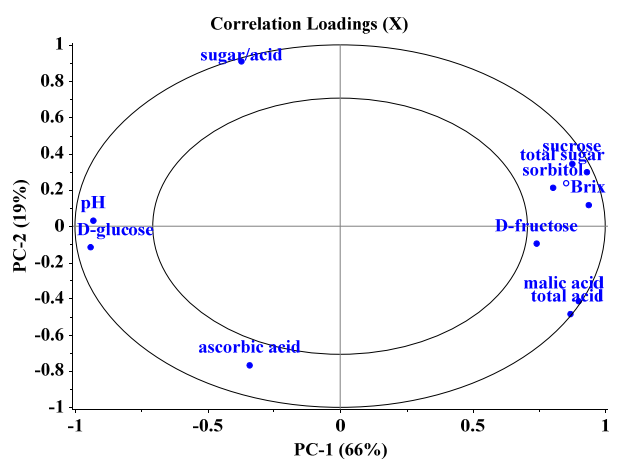

(d)

Figure 6. PCA model of cultivated apples in Yuncheng City (YC), Jinzhong City (JZ) and Linfen City (LF). (a) 'Starkrimson'. (b) ‘Golden Delicious'. (c) ‘Red General Fuji'. (d) ‘Nagafu No. 2'.

These three growth areas are similar in longitude and latitude but differed clearly in altitude. Thus, besides genetic factors, environmental factors such as altitude likely have affected the content of soluble sugars, malic acid, and ascorbic acid in the apples. The samples of Jinzhong and Linfen showed somehow similar composition likely due to the similar altitudes of these two areas. Previous studies have shown that there are altitude-associated differences in the quality of apples, and apples from lower altitude are generally described as being sweeter than the samples from higher altitude, which tend to be sourer [28]. In a recent study, the malic acid content in fruits of 'Golden Delicious' (6.5 vs. $4.9 \mathrm{mg} / \mathrm{g}$ ) and 'Red Delicious' (7.1 vs. $4.4 \mathrm{mg} / \mathrm{g}$ ) was higher in fruits grown at an altitude of $1800 \mathrm{~m}$ compared with the fruits harvested from lower altitude $(1400 \mathrm{~m})$ [37].

The correlation between altitude and composition of apple cultivars was further analyzed through Pearson correlation coefficients (Table 3). The results indicated that altitude was positively correlated with malic acid $(\mathrm{r}=0.342, p<0.01)$, sucrose $(\mathrm{r}=0.517$, $p<0.01)$, total content of acids $(\mathrm{r}=0.331, p<0.01)$, and total content of sugar $(\mathrm{r}=0.284$, $p<0.01)$ but negatively correlated with glucose $(\mathrm{r}=-0.444, p<0.01)$, sugar/acid $(\mathrm{r}=-0.218, p<0.01)$, and $\mathrm{pH}$ values $(\mathrm{r}=-0.312, p<0.01)$.

Therefore, according to the findings of the PCA and Pearson correlation analysis, as the altitude increases, the content of malic acid and sucrose increases while the content of glucose decreases. In Table 2, the detailed statistical comparison among the different altitudes of not only these four cultivars but also other cultivars collected at more than one site also indicated the above conclusions. For most of the cultivars, the contents of total acid and total sugar showed a positive correlation with altitude, while sugar/acid and $\mathrm{pH}$ were correlated negatively with altitude, which was also coincident with the results of the Pearson correlation analysis.

Previous research has shown that latitude has an impact on carbohydrate accumulation in apple peels. At high altitude $(750 \mathrm{~m})$ the content of free sugars increased in the peel of apples, while the levels of amino acids decreased compared to low altitude (20 m) [30]. 


\subsection{Correlations between Components of Cultivated Apples}

The Pearson correlation coefficients between sugars and acids of the commercially cultivated apples are shown in Table 4.

Table 4. Pearson's correlation coefficients between 11 indicators of apple cultivars.

\begin{tabular}{|c|c|c|c|c|c|c|c|c|c|c|c|}
\hline & & $\begin{array}{c}\text { Ascorbic } \\
\text { Acid }\end{array}$ & Fructose & Sorbitol & Glucose & Sucrose & $\begin{array}{l}\text { Total } \\
\text { Acid }\end{array}$ & $\begin{array}{l}\text { Total } \\
\text { Sugar }\end{array}$ & $\begin{array}{l}\text { Sugar } \\
\text { /Acid }\end{array}$ & $\mathrm{pH}$ & $\begin{array}{l}\text { Soluble } \\
\text { Solids }\end{array}$ \\
\hline \multirow{2}{*}{$\begin{array}{l}\text { Malic } \\
\text { acid }\end{array}$} & $\mathrm{r}$ & $0.443^{* *}$ & -0.009 & 0.160 * & 0.076 & $0.252 * *$ & $0.993 * *$ & $0.273^{* *}$ & $-0.862^{* *}$ & $-0.686^{* *}$ & $0.206^{*}$ \\
\hline & $p$ & $<0.001$ & 0.915 & 0.046 & 0.346 & 0.002 & $<0.001$ & 0.001 & $<0.001$ & $<0.001$ & 0.010 \\
\hline \multirow{2}{*}{$\begin{array}{c}\text { Ascorbic } \\
\text { acid }\end{array}$} & $\mathrm{r}$ & & 0.127 & $0.295^{* *}$ & $0.316^{* *}$ & 0.039 & $0.545^{* *}$ & $0.240^{* *}$ & $-0.458^{* *}$ & $-0.285^{* *}$ & $0.335^{* *}$ \\
\hline & $p$ & & 0.114 & $<0.001$ & $<0.001$ & 0.626 & $<0.001$ & 0.003 & $<0.001$ & $<0.001$ & $<0.001$ \\
\hline \multirow{2}{*}{ Fructose } & $\mathrm{r}$ & & & $0.402 * *$ & 0.032 & 0.085 & 0.009 & $0.584^{* *}$ & $0.290 * *$ & $-0.286^{* *}$ & $0.767^{* *}$ \\
\hline & $p$ & & & $<0.001$ & 0.691 & 0.292 & 0.916 & $<0.001$ & $<0.001$ & $<0.001$ & $<0.001$ \\
\hline \multirow{2}{*}{ Sorbitol } & $\mathrm{r}$ & & & & $0.241^{* *}$ & $0.210 * *$ & 0.188 * & $0.585^{* *}$ & 0.132 & 0.115 & 0.732 ** \\
\hline & $p$ & & & & 0.002 & 0.009 & 0.019 & $<0.001$ & 0.102 & 0.155 & $<0.001$ \\
\hline \multirow{2}{*}{ Glucose } & $\mathrm{r}$ & & & & & $-0.572^{* *}$ & 0.112 & -0.130 & $-0.216^{* *}$ & 0.073 & $0.218^{* *}$ \\
\hline & $p$ & & & & & $<0.001$ & 0.164 & 0.107 & 0.007 & 0.364 & 0.006 \\
\hline \multirow{2}{*}{ Sucrose } & $\mathrm{r}$ & & & & & & $0.241^{* *}$ & $0.778 * *$ & 0.086 & $-0.206^{*}$ & 0.352 ** \\
\hline & $p$ & & & & & & 0.003 & $<0.001$ & 0.289 & 0.010 & $<0.001$ \\
\hline \multirow{2}{*}{$\begin{array}{l}\text { Total } \\
\text { acid }\end{array}$} & $\mathrm{r}$ & & & & & & & $0.287^{* *}$ & $-0.866^{* *}$ & $-0.679 * *$ & $0.236^{* *}$ \\
\hline & $p$ & & & & & & & $<0.001$ & $<0.001$ & $<0.001$ & 0.003 \\
\hline \multirow{2}{*}{$\begin{array}{l}\text { Total } \\
\text { sugar }\end{array}$} & $\mathrm{r}$ & & & & & & & & 0.149 & $-0.273^{* *}$ & $0.832 * *$ \\
\hline & $p$ & & & & & & & & 0.064 & 0.001 & $<0.001$ \\
\hline \multirow{2}{*}{$\begin{array}{l}\text { Sugar/ } \\
\text { acid }\end{array}$} & $\mathrm{r}$ & & & & & & & & & $0.587^{* *}$ & $0.166^{*}$ \\
\hline & $p$ & & & & & & & & & $<0.001$ & 0.039 \\
\hline \multirow{2}{*}{$\mathrm{pH}$} & $\mathrm{r}$ & & & & & & & & & & $-0.216^{* *}$ \\
\hline & $p$ & & & & & & & & & & 0.007 \\
\hline
\end{tabular}

$*: p \leq 0.05 ; * *: p \leq 0.01$

Correlations were found between individual sugars and acids in the apple samples. Sorbitol was positively correlated with other individual sugars and acids. Sorbitol was first formed as the product of photosynthesis in leaves and was then converted to fructose, glucose, or malic acid $[15,43]$. Malic acid content was positively correlated with ascorbic acid content $(\mathrm{r}=0.443, p<0.001)$ and sucrose content $(\mathrm{r}=0.252, p=0.002)$. Previously, the content of malic acid was found to be negatively correlated with sucrose content in the fruits of apple cultivars [19]. In agreement with previous findings [19], our present study showed that the content of glucose was positively correlated with ascorbic acid content $(r=0.316, p<0.001)$, and negatively correlated with sucrose content $(r=-0.572, p<0.001)$ likely due to the conversion of sucrose to glucose and fructose [44]. In contrast to the results of our study and the study of Ma et al. [27], the research of Celik and colleagues showed a positive correlation among fructose, glucose, and sucrose content in some ancient apple cultivars [45].

As expected, the content of soluble solids was positively correlated with the content of all the sugars and acids, since all these components in apples contributed to ${ }^{\circ} \mathrm{BRIX}$ values. As expected, the $\mathrm{pH}$ value correlated negatively with the acid content and the content of individual acids but positively with the sugar/acid ratio. Total sugar was positively correlated with all the acids and sugars except glucose. In addition, the ratio of sugar/acid was negatively correlated with total acid content $(r=-0.866, p<0.001)$ but not significantly correlated with total sugar content. Previous studies have shown that the total acid content varies to a larger extent among cultivars than the sugar content in apple fruits [46,47]. This indicates total acid content to be the major contributing factor to variation in flavors, especially sweetness and sourness, among different apple cultivars. 
Therefore, more attention should be paid to the acid content in plant breeding and fruit processing.

Bioactive molecules are really important parts of the chemical composition of apples. Previously we reported the phenolic compounds in the same cultivars and wild forms of apples included in this study [48]. A total of 10 major phenolic compounds were quantified, and the influences of altitude and genetic background on these compounds were studied. The results indicated that the three wild apples have different dominant phenolic compounds, and the commercial cultivar 'Qinguan' was different from other cultivars in its high chlorogenic acid content but low proanthocyanidin content. The phenolic compounds also differed among apple cultivars based on geographical growth conditions and cultivation practice. For example, the contents of procyanidin B2 and (-)-epicatechin showed a negative correlation with altitude, while other phenolic compounds were all correlated positively with altitude [48]. Our findings of sugars, acids, and phenolic compounds of 20 cultivars and forms of apples grown in different geographical environments provide important information for the selection of materials for breeding and processing, as well as guidance for suitable location and methods for targeted cultivation.

\section{Conclusions}

The content and composition of sugars and acids are important for the quality of apple fruits. Compared with cultivated apples, the fruits of the wild apple species contained significantly higher levels of acids (malic acid), lower levels of sucrose as well as lower sugar/acid ratio. The commercial cultivars varied largely in the content of sugars, malic acid, ascorbic acid, and sugar/acid ratio. 'Gala', 'Xiali', 'Liuyuehong', 'Lihong', 'Starking Delicious', and 'Starkrimson' were characterized by higher sugar/acid ratio indicating sweeter taste compared to other cultivars. The ascorbic acid content in the commercial cultivars was highly dependent on growth location. Compared to other cultivars, 'Zhongqiuwang', 'Qinguan', and 'Nagafu No. 2' were richer in ascorbic acid regardless of the growth location. In addition to genetic factors, growth sites also affected the compositions of apples. The results from this study demonstrated that malic acid, sucrose, and total sugar content positively correlated with altitude, but glucose and the sugar/acid ratio correlated negatively. Malic acid is the major organic acid in apple fruits. High content of malic acid may increase the taste of acidity, bitterness, and astringency, therefore negatively contributing to the sensory properties of apple fruits. In this study, malic acid content was positively correlated with ascorbic acid content and sucrose content. Glucose content was positively correlated with ascorbic acid content and negatively correlated with sucrose content. Further, early-ripening cultivars tended to have higher sugar content and sugar/acid ratio and lower acid content than late-ripening cultivars. The current research provides important guidance for the breeding, selection, cultivation, and processing of apples.

Supplementary Materials: The following are available online at https:/ /www.mdpi.com/article/ 10.3390/foods10122950/s1, Table S1: The Sugars, acids, sugar/acid ratio, soluble solids, and pH of fruits of apple cultivars grown in Yuncheng, Shanxi Province, Table S2:The Sugars, acids, sugar/acid ratio, soluble solids, and $\mathrm{pH}$ of fruits of apple cultivars grown in Linfen, Shanxi Province, Table S3: The Sugars, acids, sugar/acid ratio, soluble solids, and $\mathrm{pH}$ of fruits of apple cultivars grown in Jinzhong, Shanxi Province, Figure S1:PCA model of cultivated apples by ripening time: (A) Scores plot; (B) Loadings plot. Aug represents August, Sep represents September and Oct represents October.

Author Contributions: Conceptualization, B.Y.; methodology, visualization, Y.L., H.S., W.Y. and X.M.; software, Y.L. and J.L.; validation, formal analysis, data curation, investigation, Y.L. and H.S.; resources, S.Q. and X.Q.; writing-original draft preparation, B.Y., H.S. and Y.L.; writing-review and editing, B.Y. and Y.L.; supervision, B.Y., J.L. and S.Q.; project administration, B.Y. and J.L.; funding acquisition, S.Q., X.Q. and B.Y. All authors have read and agreed to the published version of the manuscript.

Funding: The research was funded by Shanxi Academy of Agricultural Sciences in the project 'Metabolomics research and biotechnology for processing and value addition of apples' and the 
Finland-China Network in Food and Health as a pilot project of the Ministry of Education and Culture, Finland.

Institutional Review Board Statement: Not applicable.

Informed Consent Statement: Not applicable.

Data Availability Statement: Not applicable.

Acknowledgments: We are grateful to Zimian Niu (College of Horticulture, Shanxi Agricultural University) for his contribution to guidance for sample collection.

Conflicts of Interest: The authors declare no conflict of interest in this paper.

\section{References}

1. Food and Agriculture Organization. Corporate Statistical Database. FAO Online Database. Available online: http://www.fao.org/ faostat/en/\#data/QCL (accessed on 14 August 2021).

2. Janick, J. The Origins of Fruits, Fruit Growing, and Fruit Breeding. Plant Breed. Rev. 2005, 25, 255-321. [CrossRef]

3. Laurens, F.; Aranzana, M.; Bassi, D.; Bonany, J.; Corelli, L.; Durel, C.-E.; Mes, J.; Thierry, P.; Peil, A.; Quilot-Turion, B.; et al. Review of fruit genetics and breeding programmes and a new European initiative to increase fruit breeding efficiency. Acta Hortic. 2012, 929, 95-102. [CrossRef]

4. Storti, A.; Dalla Via, J.; Baric, S. Comparative molecular genetic analysis of apple genotypes maintained in germplasm collections. Erwerbs-Obstbau 2012, 54, 137-141. [CrossRef]

5. Boyer, J.; Liu, R.H. Apple phytochemicals and their health benefits. Nutr. J. 2004, 3, 5. [CrossRef]

6. Hyson, D.A. A comprehensive review of apples and apple components and their relationship to human health. Adv. Nutr. 2011, 2, 408-420. [CrossRef]

7. Tu, S.-H.; Chen, L.-C.; Ho, Y.-S. An apple a day to prevent cancer formation: Reducing cancer risk with flavonoids. J. Food Drug Anal. 2017, 25, 119-124. [CrossRef]

8. Lamperi, L.; Chiuminatto, U.; Cincinelli, A.; Galvan, P.; Giordani, E.; Lepri, L.; Del Bubba, M. Polyphenol levels and free radical scavenging activities of four apple cultivars from integrated and organic farming in different italian areas. J. Agric. Food Chem. 2008, 56, 6536-6546. [CrossRef]

9. Oszmiański, J.; Lachowicz, S.; Gławdel, E.; Cebulak, T.; Ochmian, I. Determination of phytochemical composition and antioxidant capacity of 22 old apple cultivars grown in Poland. Eur. Food Res. Technol. 2018, 244, 647-662. [CrossRef]

10. Oszmiański, J.; Lachowicz, S.; Gamsjäger, H. Phytochemical analysis by liquid chromatography of ten old apple varieties grown in Austria and their antioxidative activity. Eur. Food Res. Technol. 2020, 246, 437-448. [CrossRef]

11. Volz, R.K.; McGhie, T.K. Genetic variability in apple fruit polyphenol composition in Malus $\times$ domestica and Malus sieversii germplasm grown in New Zealand. J. Agric. Food Chem. 2011, 59, 11509-11521. [CrossRef]

12. Wu, J.; Gao, H.; Zhao, L.; Liao, X.; Chen, F.; Wang, Z.; Hu, X. Chemical compositional characterization of some apple cultivars. Food Chem. 2007, 103, 88-93. [CrossRef]

13. Begić-Akagić, A.; Spaho, N.; Gaši, F.; Drkenda, P.; Vranac, A.; Meland, M.; Salkić, B. Sugar and organic acid profiles of the traditional and international apple cultivars for processing. J. Hyg. Eng. Des. 2014, 7, 190-196.

14. Nour, V.; Trandafir, I.; Ionica, M.E. Compositional characteristics of fruits of several apple (Malus domestica Borkh.) cultivars. Not. Bot. Horti Agrobo. 2010, 38, 228-233. [CrossRef]

15. Aprea, E.; Charles, M.; Endrizzi, I.; Laura Corollaro, M.; Betta, E.; Biasioli, F.; Gasperi, F. Sweet taste in apple: The role of sorbitol, individual sugars, organic acids and volatile compounds. Sci. Rep. 2017, 7, 44950. [CrossRef]

16. Endrizzi, I.; Torri, L.; Corollaro, M.L.; Demattè, M.L.; Aprea, E.; Charles, M.; Biasioli, F.; Gasperi, F. A conjoint study on apple acceptability: Sensory characteristics and nutritional information. Food Qual. Prefer. 2015, 40, 39-48. [CrossRef]

17. Hudina, M.; Stampar, F. Sugars and organic acids contents of European (Pyrus communis L.) and Asian (Pyrus serotina Rehd.) pear cultivars. Acta Aliment. Hung. 2000, 29, 217-230. [CrossRef]

18. Petkovsek, M.M.; Stampar, F.; Veberic, R. Parameters of inner quality of the apple scab resistant and susceptible apple cultivars (Malus domestica Borkh.). Sci. Hortic.-Amst. 2007, 114, 37-44. [CrossRef]

19. Ma, B.; Chen, J.; Zheng, H.; Fang, T.; Ogutu, C.; Li, S.; Han, Y.; Wu, B. Comparative assessment of sugar and malic acid composition in cultivated and wild apples. Food Chem. 2015, 172, 86-91. [CrossRef]

20. Qin, Q.P.; Lin, F.F.; Zhang, L.L. Review of the studies on the accumulation mechanisms of sugar and organic acids in fruit Eriobotrya japonica. J. Zhejiang AF Univ. 2012, 29, 453-457. [CrossRef]

21. Gómez-Moreno, G.; Aguilar-Salvatierra, A.; Guardia, J.; Uribe-Marioni, A.; Cabrera-Ayala, M.; Delgado-Ruiz, R.A.; CalvoGuirado, J.L. The efficacy of a topical sialogogue spray containing $1 \%$ malic acid in patients with antidepressant-induced dry mouth: A double-blind, randomized clinical trial. Depress. Anxiety 2013, 30, 137-142. [CrossRef]

22. Gómez-Moreno, G.; Guardia, J.; Aguilar-Salvatierra, A.; Cabrera-Ayala, M.; Maté-Sánchez de-Val, J.-E.; Calvo-Guirado, J.-L. Effectiveness of malic acid $1 \%$ in patients with xerostomia induced by antihypertensive drugs. Med. Oral Patol. Oral Cir. Bucal 2013, 18, e49-e55. [CrossRef] 
23. Rodgers, A.L.; Webber, D.; de Charmoy, R.; Jackson, G.E.; Ravenscroft, N. Malic acid supplementation increases urinary citrate excretion and urinary $\mathrm{pH}$ : Implications for the potential treatment of calcium oxalate stone disease. J. Endourol. 2014, 28, 229-236. [CrossRef] [PubMed]

24. Tang, X.; Liu, J.; Dong, W.; Li, P.; Li, L.; Lin, C.; Zheng, Y.; Hou, J.; Li, D. The cardioprotective effects of citric Acid and L-malic Acid on myocardial ischemia/reperfusion injury. Evid. Based Complement Altern. Med. 2013, 2013, 820695. [CrossRef]

25. Kowitcharoen, L.; Wongs-Aree, C.; Setha, S.; Komkhuntod, R.; Kondo, S.; Srilaong, V. Pre-harvest drought stress treatment improves antioxidant activity and sugar accumulation of sugar apple at harvest and during storage. Agric. Nat. Resour. 2018, 52, 146-154. [CrossRef]

26. Musacchi, S.; Serra, S. Apple fruit quality: Overview on pre-harvest factors. Sci. Hortic.-Amst. 2018, 234, 409-430. [CrossRef]

27. Giné-Bordonaba, J.; Echeverria, G.; Duaigües, E.; Bobo, G.; Larrigaudière, C. A comprehensive study on the main physiological and biochemical changes occurring during growth and on-tree ripening of two apple varieties with different postharvest behaviour. Plant Physiol. Biochem. 2019, 135, 601-610. [CrossRef] [PubMed]

28. Charles, M.; Corollaro, M.L.; Manfrini, L.; Endrizzi, I.; Aprea, E.; Zanella, A.; Corelli Grappadelli, L.; Gasperi, F. Application of a sensory-instrumental tool to study apple texture characteristics shaped by altitude and time of harvest. J. Sci. Food Agric. 2018, 98, 1095-1104. [CrossRef] [PubMed]

29. Hudina, M.; Stampar, F. Influence of frost damage on the sugars and organic acids contents in apple and pear flowers. Europ. J. Hort. Sci. 2006, 71, 161-164.

30. Karagiannis, E.; Michailidis, M.; Tanou, G.; Scossa, F.; Sarrou, E.; Stamatakis, G.; Samiotaki, M.; Martens, S.; Fernie, A.R.; Molassiotis, A. Decoding altitude-activated regulatory mechanisms occurring during apple peel ripening. Hortic. Res. 2020, 7 , 120. [CrossRef]

31. National Bureau of Statistics of the People's Republic of China. China Statistical Yearbook; China Statistics Press: Beijing, China, 2018; Volume 12.

32. Fan, J.; Liu, Z.; Du, E.; Gao, Y.; Ren, H.; Zhang, P.; Zhang, H.; Fan, R. A brief review of the apple industry in Shanxi province in the process of economic transition. Agric. Technol. Equip. 2017, 328, 7-11. [CrossRef]

33. Füzfai, Z.; Katona, Z.F.; Kovács, E.; Molnár-Perl, I. Simultaneous identification and quantification of the sugar, sugar alcohol, and carboxylic acid contents of sour cherry, apple, and ber fruits, as their trimethylsilyl derivatives, by gas chromatography-mass spectrometry. J. Agric. Food Chem. 2004, 52, 7444-7452. [CrossRef] [PubMed]

34. Wang, B.; Dong, Z.; Zhang, X.; Bao, M.; Fu, J. High quality griggles-'Saiwaihong' selective breeding. J. Fruit Sci. 2014, 31, 739-741. [CrossRef]

35. Parker, I.M.; López, I.; Petersen, J.J.; Anaya, N.; Cubilla-Rios, L.; Potter, D. Domestication syndrome in caimito (Chrysophyllum cainito L.): Fruit and seed characteristics. Econ. Bot. 2010, 64, 161-175. [CrossRef]

36. Hecke, K.; Herbinger, K.; Veberic, R.; Trobec, M.; Toplak, H.; Stampar, F.; Keppel, H.; Grill, D. Sugar-, acid- and phenol contents in apple cultivars from organic and integrated fruit cultivation. Eur. J. Clin. Nutr. 2006, 60, 1136-1140. [CrossRef] [PubMed]

37. Kumar, P.; Sethi, S.; Sharma, R.R.; Singh, S.; Saha, S.; Sharma, V.K.; Sharma, S.; Varghese, E. Influence of altitudinal variation on the physical and biochemical characteristics of apple (Malus demostica). Indian J. Agric. Sci. 2019, 89, 145-152.

38. Planchon, V.; Lateur, M.; Dupont, P.; Lognay, G. Ascorbic acid level of Belgian apple genetic resources. Sci. Hortic.-Amst. 2004, 100, 51-61. [CrossRef]

39. Li, M.-J.; Ma, F.-W.; Zhang, M.; Pu, F. Distribution and metabolism of ascorbic acid in apple fruits (Malus domestica Borkh cv. Gala). Plant Sci. 2008, 174, 606-612. [CrossRef]

40. Bassi, M.; Lubes, G.; Bianchi, F.; Agnolet, S.; Ciesa, F.; Brunner, K.; Guerra, W.; Robatscher, P.; Oberhuber, M. Ascorbic acid content in apple pulp, peel, and monovarietal cloudy juices of 64 different cultivars. Int. J. Food Prop. 2018, 20, S2626-S2634. [CrossRef]

41. Nookaraju, A.; Upadhyaya, C.P.; Pandey, S.K.; Young, K.E.; Hong, S.J.; Park, S.K.; Park, S.W. Molecular approaches for enhancing sweetness in fruits and vegetables. Sci. Hortic.-Amst. 2010, 127, 1-15. [CrossRef]

42. Cornille, A.; Giraud, T.; Smulders, M.J.; Roldán-Ruiz, I.; Gladieux, P. The domestication and evolutionary ecology of apples. Trends Genet. 2014, 30, 57-65. [CrossRef]

43. Yamaki, S. Metabolism and accumulation of sugars translocated to fruit and their regulation. J. Jpn. Soc. Hort. Sci. 2010, 79, 1-15. [CrossRef]

44. Chardonnet, C.O.; Charron, C.S.; Sams, C.E.; Conway, W.S. Chemical changes in the cortical tissue and cell walls of calciuminfiltrated 'Golden Delicious' apples during storage. Postharvest Biol. Technol. 2003, 28, 97-111. [CrossRef]

45. Celik, F.; Gundogdu, M.; Kaki, B.; Kuru Berk, S.; Ilhan, G.; Sağbaş, H. Variation in organic acid, sugar and phenolic compounds in fruits of historical apple cultivars. Not. Bot. Horti Agrobot. 2018, 46, 622-629. [CrossRef]

46. Yao, G.-F.; Zhang, S.-L.; Wu, J.; Cao, Y.-F.; Liu, J.; Han, K.; Yang, Z.-J. Analysis of components and contents of soluble sugars and organic acids in ten cultivars of pear by high performance liquid chromatography. J. Nanjing Agric. Univ. 2011, $34,25-31$. [CrossRef]

47. Zheng, L.-J.; Nie, J.-Y.; Yan, Z. Advances in research on sugars, organic acids and their effects on taste of fruits. J. Fruit Sci. 2015, 32, 304-312. [CrossRef]

48. Li, Y.; Sun, H.; Li, J.; Qin, S.; Niu, Z.; Qiao, X.; Yang, B. Influence of genetic background, growth latitude and bagging treatment on phenolic compounds in fruits of commercial cultivars and wild types of apples (Malus sp.). Eur. Food Res. Technol. 2021, 247, 1149-1165. [CrossRef] 